\title{
Accounting Data, Market Values, and the Cross Section of Expected Returns Worldwide
}

\section{Citation}

Chattopadhyay, Akash, Matthew R. Lyle, and Charles C.Y. Wang. "Accounting Data, Market Values, and the Cross Section of Expected Returns Worldwide." Harvard Business School Working Paper, No. 15-092, June 2015. (Revised August 2015.)

\section{Permanent link}

http://nrs.harvard.edu/urn-3:HUL.InstRepos:16198221

\section{Terms of Use}

This article was downloaded from Harvard University's DASH repository, and is made available under the terms and conditions applicable to Open Access Policy Articles, as set forth at http:// nrs.harvard.edu/urn-3:HUL.InstRepos:dash.current.terms-of-use\#OAP

\section{Share Your Story}

The Harvard community has made this article openly available.

Please share how this access benefits you. Submit a story.

Accessibility 


\section{Accounting Data, Market Values, and the Cross Section of Expected Returns Worldwide}

Akash Chattopadhyay

Matthew R. Lyle

Charles C.Y. Wang

Working Paper 15-092 


\title{
Accounting Data, Market Values, and the Cross Section of Expected Returns Worldwide
}

\author{
Akash Chattopadhyay \\ Harvard Business School \\ Matthew R. Lyle \\ Kellogg School of Management \\ Charles C.Y. Wang \\ Harvard Business School
}

Working Paper 15-092 


\title{
Accounting Data, Market Values, and the Cross Section of Expected Returns Worldwide
}

\author{
Akash Chattopadhyay \\ Harvard Business School \\ Matthew R. Lyle \\ Kellogg School of Management \\ Charles C.Y. Wang* \\ Harvard Business School
}

August 2015

\begin{abstract}
Under fairly general assumptions, expected stock returns are a linear combination of two accounting fundamentals - book to market and ROE. Empirical estimates based on this relation predict the cross section of out-of-sample returns in 26 of 29 international equity markets, with a highly significant average slope coefficient of 1.05 . In sharp contrast, standard factor-model-based proxies fail to exhibit predictive power internationally. We show analytically and empirically that the importance of ROE in forecasting returns depends on the quality of accounting information. Overall, a tractable accounting-based valuation model provides a unifying framework for obtaining reliable proxies of expected returns worldwide.
\end{abstract}

Keywords: Expected returns, discount rates, fundamental valuation, present value, information quality, international equity markets.

JEL: D83, G12, G14, M41

*Chattopadhyay (achattopadhyay@hbs.edu) is a doctoral candidate in Accounting and Management at Harvard Business School. Lyle (m-lyle@kellogg.northwestern.edu) is Assistant Professor of Accounting Information and Management and The Lawrence Revsine Research Fellow at Kellogg School of Management. Wang (charles.cy.wang@hbs.edu) is Assistant Professor of Business Administration at Harvard Business School. For helpful comments and suggestions, we are grateful to Ryan Buell, Craig Chapman, Peter Easton, Ian Gow, Jeremiah Green (FARS discussant), Daniel Malter, Jim Naughton, Tatiana Sandino, Pian Shu, Beverly Walther, Clare Wang, James Zeitler, and to workshop participants at University of Alberta, Arizona State University, Citadel Quantitative Research, Duke University, Harvard Business School, University of Illinois, Kellogg School of Management, University of Miami, National Chengchi University, as well as participants at the 2015 FARS conference and Minnesota Empirical Accounting Research Conference. We thank Kyle Thomas for excellent research assistance. Lyle is grateful for generous funding provided through the Lawrence Revsine Research Fellowship. 


\section{Introduction}

Estimating expected returns has been a centerpiece in financial economics since at least the derivation of the CAPM (Sharpe, 1964). Over the past thirty years, the central organizing theoretical and empirical question in asset pricing is understanding what drives the variation in expected returns (Cochrane, 2011). Capital markets research in accounting has also developed a large and growing literature examining how different firm attributes or policies - e.g., disclosure policies (Botosan, 1997), audit quality (Chen, Chen, Lobo, and Wang, 2011), or corporate governance and regulatory institutions (Hail and Leuz, 2006)—affect expected returns.

Despite its importance, empirical research in this area remains problematic, and results are often controversial because the key dependent variable - expected returns - is not directly observable, notoriously difficult to measure, and there is no well-accepted standard for its estimation. We posit that such a standard should, by definition, produce empirical proxies that on average forecast the cross-section of future returns and across multiple equity markets. Despite extensive work on this measurement problem, to our knowledge no such method exists.

Factor-based models, like the capital asset pricing model or the Fama and French (1993) factor model, are unreliable proxies of ex ante expected returns as they fail to exhibit out-of-sample predictive ability in the U.S. (Lee, So, and Wang, 2014; Lyle and Wang, 2015). The accounting literature's development of the implied cost of capital (ICC) class of expected return proxies (ERPs), as an alternative to factor-based proxies, have so far failed to produce a well-accepted standard. ${ }^{1}$ This may be in part due to the restrictive assumptions that underlie ICC models (e.g., constant expected returns, adhoc terminal growth assumptions), the difficulties in their implementation (e.g., solving

\footnotetext{
${ }^{1}$ Recent examples of papers that explore the performance of these and other expected-return proxies include: Botosan and Plumlee (2005); Botosan, Plumlee, and Wen (2011); Easton and Monahan (2005); Lyle, Callen, and Elliott (2013); Lee et al. (2014); Lyle and Wang (2015); Wang (2015).
} 
non-linear equations by numerical methods that may or may not converge, or that may converge to multiple solutions), and, perhaps most saliently, the lack of evidence that ICCs, in the cross section, line up well with true expected returns (Easton and Monahan, 2005; Lee et al., 2014).

These empirical challenges are exacerbated in international settings (Lee, Ng, and Swaminathan, 2009). Varying degrees in the integration with global markets, differences in regulatory and governance institutions, the relative paucity of international data, and differences in accounting reporting standards represent significant barriers to a uniform standard or framework for estimating firm-level expected returns worldwide. Indeed, prior work shows that factors known to explain the in-sample variation of returns in the United States do not necessarily explain the cross section of returns in other markets internationally (Fama and French, 2012; Hou, Karolyi, and Kho, 2011). It is perhaps unsurprising, therefore, that there is no well-accepted and theoretically-motivated standard for estimating firm-level expected returns not only in the U.S. setting, but also across international markets.

In this paper we show, both analytically and empirically, that a simple and parsimonious accounting-based approach can offer a step forward to solving this long-standing measurement problem. We derive, under fairly general assumptions, an accounting-based ERP that (i) can forecast the cross-section of future returns worldwide and (ii) lines up well with true expected returns. Our work validates and builds on, in three ways, the findings of Lyle and Wang (2015) (subsequently referred to as LW15), who apply the log-linearization of Vuolteenaho (2002) to derive a tractable model of time-varying expected rate of return that is a linear function of the book-to-market ratio (BM) and return-on-equity (ROE).

First, we show analytically that the accounting-based model of expected returns in LW15 is quite robust and can be applied to a broad set of firms regardless of dividend 
payout policy. Like LW15, we show that a parsimonious solution for estimating firm-level expected returns requires only a linear combination of two accounting fundamentals: BM and ROE. But we derive this solution under more generalized and milder assumptions: 1) the book-to-market ratio is a weakly stationary process and that 2) expected growth rates in market and book are mean-reverting. Thus we generalize LW15 by showing that this linear relation between expected returns and fundamentals holds even if firms do not pay dividends, rather than the assumption of firm-level dividend payments implicit in the Vuolteenaho (2002) approach. $^{2}$

Second, we extend to and validate in an international setting the empirical findings of LW15, who focus only on U.S. equities. Our simple accounting-based ERPs perform well across the world: they significantly and reliably predict the cross section of stock returns in 26 of 29 equity markets worldwide. They also line up well with true expected returns. Fama-MacBeth (FM) regression tests - regressing one-month-ahead returns on ex-ante proxies of expected returns - yield an average predictive slope coefficient of 1.05 (relative to the absolute benchmark of 1). For 21 (20) of the 29 countries the predictive slope is not significantly different from 1 at the 10\% (5\%) level. Portfolio-based tests yield similar conclusions.

Finally, we build upon LW15 by examining, both analytically and empirically, how the quality of accounting information affects the relation between accounting numbers and expected returns. By relating the accounting-based model of expected returns to a dynamic information structure, we show analytically that, holding all other sources of information constant, higher-quality accounting information - defined by lower measurement error variance - increases the importance of ROE in determining expected returns. These predictions are supported by our empirical tests. Relying on measures of countrylevel earnings quality derived from Leuz, Nanda, and Wysocki (2003) and employing

\footnotetext{
${ }^{2}$ The log-linearization approach of Vuolteenaho (2002) requires that firm's pay dividends.
} 
an instrumental variables estimation strategy, we document that, all else equal, higher earnings quality elevates the importance of ROE in inferring expected returns. Together, we contribute to the literature by providing a simple accounting-based ERP that can be applied to international markets and by demonstrating how the quality of accounting systems impacts the importance of accounting-information in this proxy.

Our work relates to the extensive value-relevance literature in accounting that connects prices to accounting data, and in particular to the seminal work of Ohlson (1995) and Feltham and Ohlson (1995) that relate firm values to accounting data through the residual income model. Our approach to deriving firm values is similar; however, unlike the prior papers, we do not assume clean surplus, risk neutrality, and importantly allow both growth rates in book and stock values to vary stochastically through time.

Our work also relates to the rich implied cost of capital literature in accounting (e.g., Botosan, 1997; Gebhardt, Lee, and Swaminathan, 2001; Claus and Thomas, 2001; Gode and Mohanram, 2003; Easton, 2004) in that we also seek to infer expected returns implied by observed stock prices and accounting data. Our approach, though similar in principle, has several distinct practical advantages. Ours is motivated by a fairly general model, applicable to broad classes of accounting systems, easy to implement, and does not require solving non-linear equations. Further, our ERPs line up well with true expected returns across international equity markets.

Our paper is also related to the large body of research in accounting and finance linking stock returns to firm characteristics (e.g., Banz, 1981; Rosenberg, Reid, and Lanstein, 1985; Bernard and Thomas, 1990; Fama and French, 1992; Jegadeesh, Jegadeesh, Titman, and Titman, 1993; Haugen and Baker, 1996; Sloan, 1996; Daniel, Grinblatt, Titman, and Wermers, 1997; Piotroski, 2000; Fama and French, 2008; Penman, Reggiani, Richardson, and Tuna, 2013). ${ }^{3}$ Our study differs from these in that we contribute by showing whether

\footnotetext{
${ }^{3}$ See Green, Hand, and Zhang (2013) or Lewellen (2015) for a summary of the firm characteristics that have been identified to be associated with future returns.
} 
and how investors can combine firm characteristics to form ERPs that line up well with true expected returns, a subject that has received relatively little (but growing) attention (e.g., Lewellen, 2015; Lyle et al., 2013; Lyle and Wang, 2015; Lee et al., 2014).

Aside from LW15, closest to the present study is Lewellen (2015), which also studies how firm characteristics can be combined to form reliable ERPs using historical FM regressions, and Haugen and Baker (1996), which also assesses the usefulness of historical FM regressions. Our work differs from these in that we focus on two firm characteristics motivated by valuation theory instead of a large set of ad hoc [and in the case of Haugen and Baker (1996) short-lived] predictors. Moreover, our analyses are focused on a large set of international markets, for which there is relatively little evidence on the performance of cross-sectional-regression-based estimates of firm-level expected returns. ${ }^{4}$ Our findings suggest that an accounting-based valuation model can serve as a unifying framework for estimating firm-level expected rates of return across markets worldwide.

Though the primary contribution of this paper is to demonstrate that a simple and reliable ERP that lines up well with true expected returns can be obtained from a linear combination of only two firm fundamentals, we wish to emphasize a subtler but important contribution of our analytical work. In relating our accounting-based expected returns model to a dynamic information setting, we are able to offer new insights that would not be possible using traditional CAPM or ICC expected return models. First, this framework allows us to analyze how accounting information quality impacts expected returns through fundamentals. How accounting information quality impacts expected returns is a long standing question in accounting research, a question that is difficult to address in large part because models of expected returns that allow for information quality variation (e.g., Lambert, Leuz, and Verrecchia, 2007) are not functions of actual accounting data. Our analytical approach takes a step towards dealing with this issue. Second, this extension

\footnotetext{
${ }^{4}$ Lewellen (2015) studies the U.S. market exclusively. Haugen and Baker (1996) focuses mainly on the U.S. but performs an analysis on France, Japan, Germany, and the U.K.
} 
provides a framework for understanding why various characteristics (accounting data and valuation ratios) relate to future stock returns: they carry information about future ROE. This analytical result suggests that the empirical approach used by Ou and Penman (1989), coupled with our parsimonious model, may offer an exciting area of potential future research in accounting and characteristic-based asset pricing.

The remainder of the paper is organized as follows. Section 2 presents the accountingbased model for estimating expected returns. Section 3 discusses the estimation of the model and presents our empirical findings. Section 4 presents our theoretical and empirical analyses of the role of accounting-information quality. Section 5 concludes the paper.

\section{The Model}

In this section, we derive a model of expected returns that is a linear combination of BM and expected ROE, as in LW15. However, our derivation relies on a milder set of assumptions that generalizes the result of LW15 and allows for the application of this model to a wider range of firms (non-dividend payers).

\subsection{Main Assumptions and the Set Up}

Two main assumptions anchor the present model. First, instead of relying on the log-linearization of Vuolteenaho (2002), we make the mild assumption that the log bookto-market ratio $(b m)$ is covariance-stationary with finite first moment: ${ }^{5}$

$$
\lim _{j \rightarrow \infty} \mathbb{E}_{t}\left[\log \left(\frac{B_{t+j}}{M_{t+j}}\right)\right]=\overline{b m}<\infty .
$$

\footnotetext{
${ }^{5}$ This assumption is consistent with that of Daniel et al. (1997), who assume that a long-term bookto-market ratio is measurable.
} 
Unlike the assumption required in Vuolteenaho (2002) — that firm's must pay dividends this milder assumption allows us to solve for equity values regardless of dividend policy. Aside from generalizability, the weak stationarity assumption is also motivated and supported empirically in untabulated tests. ${ }^{6}$

Second, we assume that expected growth rates in the market value of equity, $\mathbb{E}_{t}\left[g_{m, t+1}\right] \equiv$ $\mu_{t}$, and the book value of equity, $\mathbb{E}_{t}\left[g_{b, t+1}\right] \equiv h_{t}$, are time-varying and mean-reverting. We model them to follow $\mathrm{AR}(1)$ processes:

$$
\begin{aligned}
& \mu_{t+1}=\mu+\kappa\left(\mu_{t}-\mu\right)+\xi_{t+1}, \text { and } \\
& h_{t+1}=\mu+\omega\left(h_{t}-\mu\right)+\epsilon_{t+1},
\end{aligned}
$$

where $\kappa$ and $\omega$ represent the levels of persistence in expected market and book growth, respectively; $\mu$ represents the unconditional average expected growth rates for both market and book; and the vector of innovations $\left(\xi_{t+1}, \epsilon_{t+1}\right)$ are IID through time with zero means and a positive semi-definite covariance matrix. ${ }^{7}$

The $\mathrm{AR}(1)$ assumption for expected market growth is consistent with time-varying and persistent expected returns and follows prior research (e.g., Campbell, 1991; van Binsbergen and Koijen, 2010; Pástor and Stambaugh, 2012; Lyle and Wang, 2015). The assumption for expected book growth captures the idea that competitive forces drive a tendency of accounting rates of returns to revert to a steady-state mean (e.g., Beaver, 1970; Penman, 1991; Pástor and Veronesi, 2003; Healy, Serafeim, Srinivasan, and Yu, 2014). The above also assumes that expected market and book growth revert to a common mean, which is not only consistent with the stationarity in $b m$ but also motivated by the

\footnotetext{
${ }^{6}$ Analyzing the aggregate annual $\mathrm{bm}$ series across countries using standard Dickey-Fuller tests, we reject the null of non-stationarity for the vast majority of countries.

${ }^{7}$ Contemporaneous correlations between the innovation in expected book and market growth are possible under this assumption. Thus, while innovations in expected market growth are not correlated over time, i.e., $\operatorname{cov}_{t}\left(\xi_{t+n}, \xi_{t+k}\right)=0$, and the innovations in book growth are not correlated over time, i.e., $\operatorname{cov}_{t}\left(\epsilon_{t+n}, \epsilon_{t+k}\right)=0$, the only restriction on the contemporaneous covariance between innovations in book and market growth is boundedness, i.e., $\left|\operatorname{cov}_{t}\left(\epsilon_{t+k}, \xi_{t+k}\right)\right|<\infty$.
} 
idea that in the long-run abnormal growth in book values should converge to 0 due to competition (e.g., Ohlson, 1995). In untabulated tests we also find empirical support for these assumptions. ${ }^{8}$

Under these two main assumptions, we can relate $b m_{t}, \mu_{t}$, and $h_{t}$ parsimoniously. Letting $M_{t}, B_{t}, G_{m, t+1}$, and $G_{b, t+1}$ denote market value, book value, growth in market value, and growth in book value, respectively, we can relate two periods' market and book values as follows:

$$
B_{t+1}=G_{b, t+1} B_{t} \text { and } M_{t+1}=G_{m, t+1} M_{t}
$$

Taking logs and subtracting log market $(m)$ from log book $(b)$ values yields

$$
b m_{t}=b m_{t+1}+g_{m, t+1}-g_{b, t+1} .
$$

Iterating Eq., (5) forward, using the Eq., (1) assumption, and taking expectations conditional on information known at time $t, b m_{t}$ can be expressed as

$$
b m_{t}=\overline{b m}+\sum_{i=1}^{\infty} \mathbb{E}_{t}\left[g_{m, t+i}-g_{b, t+i}\right] .
$$

Given the stationarity of $b m$ (so that $b m_{t}$ is bounded for any $t$ ), this expression implies that growth rates of book and market values must be expected to converge,

$$
\lim _{T \rightarrow \infty} \mathbb{E}_{t}\left[g_{m, t+T}-g_{b, t+T}\right]=0,
$$

implying a common mean assumption in these expected growth rates. Finally, under the

\footnotetext{
${ }^{8}$ In a vast majority of the countries in our sample, we find substantial support for the hypothesis that the realized aggregate series in the growth in market and book values are generated by $\operatorname{ARMA}(1,1)$ processes, consistent with expected book and market growth being AR(1) (Hamilton, 1994). Moreover, in all of the countries in our sample, we are unable to reject the null that the mean growth in book and the mean growth in market values are different from one another.
} 
$\mathrm{AR}(1)$ structure, the appendix shows that $b m_{t}$ can be simplified as

$$
b m_{t}=\overline{b m}+\frac{1}{1-\kappa}\left(\mu_{t}-\mu\right)-\frac{1}{1-\omega}\left(h_{t}-\mu\right) .
$$

\section{$2.2 \quad$ Expected Returns}

Our goal is to solve for next period expected returns, conditional on information known at time $t$. Expected log-returns, is defined as:

$$
\mathbb{E}_{t}\left[r_{t+1}\right]=\mathbb{E}_{t}\left[\log \left(\frac{M_{t+1}+D_{t+1}}{M_{t}}\right)\right]
$$

where $M_{t}$ and $D_{t}$ are the time- $t$ market value and dividends, respectively.

Armed with the bm ratio in Eq., (8) and assuming, as in Pástor and Veronesi (2003), that accounting satisfies clean surplus and that dividends are proportional to book value over the next interval, we show in the Appendix that expected returns is a linear combination of the book-to-market ratio and expected ROE:

$$
\mathbb{E}_{t}\left[r_{t+1}\right]=A_{1}+A_{2} b m_{t}+A_{3} \mathbb{E}_{t}\left[\text { roe }_{t+1}\right]
$$

where $A_{1}=K-(1-\kappa+\rho \kappa) \overline{b m}-A_{3} \log (1+\delta)+\frac{(\kappa-\omega)(1-\rho)}{(1-\omega)} \mu, A_{2}=1-\kappa+\rho \kappa$, and $A_{3}=\frac{\rho(\kappa-\omega)+1-\kappa}{1-\omega} ; \delta$ is the proportion of dividends paid out of book; the constants $K$ and $\rho$ are by-products of a log-linearization around the unconditional $\mathrm{bm}$ ratio and close to zero in value. Thus, even under these rather mild assumptions, as in LW15, expected log returns can be determined by a constant, $b m$, and expected roe. ${ }^{9}$

The intuition for why $b m$ and roe provide information on expected returns resides in the present value relation between prices, expected future payoffs, and expected returns.

\footnotetext{
${ }^{9}$ The interpretation of the coefficients in this paper, however, is slightly different. In LW15, $A_{1}=$ $\frac{(\omega-\kappa) k_{1}}{1-\omega k_{1}} \mu, A_{2}=1-\kappa k_{1}$, and $A_{3}=\frac{1-\kappa k_{1}}{1-\omega k_{1}}$, where $k_{1}$ is a linearization constant assumed to be close to one.
} 
Accounting fundamentals provide information on expected future payoffs (cash flows), while market prices provide information on both expected future payoffs and how they are discounted. Thus combining market values with accounting numbers, rather than the latter per se, reveal expected returns.

Consider for illustration the classic Gordon Growth Model, which relates market values $\left(M_{t}\right)$ to dividends $\left(D_{t}\right)$ as well as constant dividend growth $(g)$ (i.e., expected future payoffs) and constant expected return $(r)$ :

$$
M_{t}=D_{t} \frac{1+g}{r-g}
$$

This model implies that the expected return is a function of expected future fundamentals (i.e., dividends and dividend growth) and market price:

$$
r=\frac{D_{t}}{M_{t}}(1+g)+g
$$

While contrived, this example illustrates the intuition that expected returns are revealed by combining market values and "adding back" expected future payoffs. Moreover, assuming that dividends are proportional to book value, future payoffs can be expressed in terms of accounting fundamentals (i.e., book value and earnings). ${ }^{10}$ Our model can be interpreted using this intuition, but it is more general in that we allow expected returns and future payoffs, expressed in terms of accounting fundamentals, to be dynamic. Following the intuition above, holding expected future payoffs fixed (e.g., holding fixed current book value and expected future roe), lower market values reflect higher expected

\footnotetext{
${ }^{10}$ Alternatively, similar intuition can be gleaned from a classic steady-state residual income model:

$$
M_{t}=B_{t}+\frac{\left(r o e^{*}-r\right) B_{t}}{r-g}
$$

where $r$ is expected returns, $g$ is the growth in book value and net income, and roe* is the steady-state return-on-equity.
} 
returns [i.e., positive $A_{2}$ in (10)]. Similarly, holding market prices fixed, greater expected future payoffs (e.g., higher future roe) reflects higher expected returns [i.e., positive $A_{3}$ in (10)].

\section{Model Calibration and Main Empirical Tests}

This section describes the process of estimating Eq., (10), including the data requirements and key inputs, to compute the model-implied estimates of expected returns. We then present our main empirical tests to assess the out-of-sample cross-sectional performance of these estimates.

\subsection{Data and Calibration}

To calibrate the model we make the following assumptions on the relations between realized and expected returns and roe:

$$
\begin{aligned}
r_{i, t+1} & =\mathbb{E}_{t}\left[r_{i, t+1}\right]+\eta_{i, t+1}, \\
\operatorname{roe}_{i, t+1} & =\mathbb{E}_{t}\left[\text { roe }_{i, t+1}\right]+\nu_{i, t+1},
\end{aligned}
$$

where $\left(\eta_{i, t+1}, \nu_{i, t+1}\right)$ are IID noise terms with zero mean and a positive semi-definite covariance matrix. ${ }^{11}$ Substituting into Eq., (10) and applying the $\mathrm{AR}(1)$ assumption to expected log book growth yields the following estimable equation relating one-period ahead realized returns to current $b m$ ratios and roe:

$$
r_{i, t+1}=\beta_{1}+\beta_{2} b m_{i, t}+\beta_{3} r o e_{i, t}+\zeta_{i, t+1}
$$

\footnotetext{
${ }^{11}$ The uncorrelatedness and zero mean assumptions follow from the properties of conditional expectations (e.g., Angrist and Pischke, 2008). Note that while expected return and expected return-on-equity innovations are independent over time, they can be contemporaneously correlated.
} 
where $\beta_{1}=K+\left(1-\kappa+\frac{(\kappa-\omega)(1-\rho \omega)}{1-\omega}\right) \mu-(1-\kappa+\rho \kappa) \overline{b m}-\omega A_{3} \log (1+\delta), \beta_{2}=A_{2}=$ $1-\kappa+\rho \kappa, \beta_{3}=\omega A_{3}=\omega \frac{\rho(\kappa-\omega)+1-\kappa}{1-\omega}$, and $\zeta_{i, t+1}=A_{3}\left(\epsilon_{t}-\omega \nu_{t}\right)-\eta_{t+1}$. Again, $K=$ $\log (1+\delta \exp (\overline{b m}))$ and $\rho=\frac{\delta \exp (\overline{b m})}{1+\delta \exp (\overline{b m})}$ are by-products of the log linearization.

Calibrating the model requires us to specify the frequency with which expected returns and expected roe evolve according to the assumed dynamics. For example, LW15 choose quarterly and annual frequencies. A challenge in the international setting is that the mandatory frequency of interim reporting is not uniform across markets in different countries; moreover, some countries changed their mandatory interim financial-reporting frequency during our sample period (e.g., Link, 2012).

Because annual reporting is required in all countries in our sample, a natural empirical specification would be to match annual stock returns to annual $b m$ and roe. Given that fundamental data for most countries become available for a suitable cross section only between the early and mid-1990s, using annual data imposes serious limitations on the time series data available to us. The lack of consistency in quarterly reporting across countries also limits the usefulness of switching to interim reporting.

Our approach to resolving this empirical issue, similar to that of Fama and French (1992), is to match one-month-ahead returns to annual fundamental data (i.e., matching one-month-ahead returns to $\mathrm{bm}$ and annual roe). This can be thought of as treating the annual version of Eq., (13) as the sum of 12 equations that contain monthly returns and news. In this framework, each of the 12 months in a given year is an estimation equation, using the same BM and annual ROE, and the sum of the 12 estimated monthly coefficients translates to the coefficients of an annual model. We assume fundamental data to be known publicly and observable to the researcher four months after the fiscalyear-end date. ${ }^{12}$ Thus, in computing a firm's BM, we use its market capitalization on the

\footnotetext{
${ }^{12}$ This assumption is necessitated by the sparseness of the earnings announcement date variable for a number of countries in Compustat Global. However, among those firms in our sample with earnings announcement dates, greater than 90 percent of them report annual earnings within four months of the fiscal year end.
} 
last trading day of the fourth month after the last fiscal-year-ending month.

Our data on returns and fundamentals come from Compustat Global and Compustat North America (in the case of Canada and the U.S.). ${ }^{13}$ Monthly returns are computed using Compustat's price variable (variable prccd from the price file) by applying adjustments for splits and dividends using the respective adjustment factors (variables ajexdi and trfd from the price file). ${ }^{14}$ Gross annual ROE is calculated as $R O E_{i, t}=\left(1+\frac{X_{i, t}}{B o o k_{i, t-1}}\right)$, where $X_{i, t}$ is Net Income before Extraordinary Items (variable $i b$ from the fundamentals file) and $B_{0 o k_{i, t-1}}$ is the lag Book Value of Common Equity (variable ceq from the fundamentals file).

We make forecasts of expected future monthly (log) returns by estimating Eq. (13), via FM regressions, using historical realized monthly returns, the $b m$ ratio, and roe that are observable as of the forecast date to avoid look-ahead bias. To ensure stability in the FM coefficients, we use a training (or burn-in) sample consisting of 40 months in each country, after which out-of-sample forecasting and testing begins. We use a "cumulative" window approach, or recursive estimation, in that all historical data available at the time of the forecast are used to estimate Eq., (13) in order to form expected returns. In other words, we forecast one-month-ahead expected $r$ at the end of each calendar month by applying historically-estimated FM coefficients on the $b m$ and roe values observed as of the forecast date.

Embedded in our country-specific and recursive estimation choices are the implicit assumptions that 1) expected market growth and expected book growth follow $\mathrm{AR}(1)$ processes with a common long-run mean; 2) these model parameters are country-specific and may be time-varying; and 3) expected dividend payout ratios are country-specific and

\footnotetext{
${ }^{13}$ While our use of Compustat for international fundamentals and returns data follows some prior literature (e.g., Bushman and Piotroski, 2006, Novy-Marx, 2013), the international capital markets literature has also used Datastream as a common alternative. Though ex ante we do not expect our findings to be influenced by this choice, we re-estimate our main results, in untabulated robustness tests, for a set of major countries using Datastream and find nearly identical results.

${ }^{14}$ Specifically, log gross returns from $t$ to $t+1$ is computed as $\log \left(\frac{p r c c d_{t+1} \times \operatorname{trf} d_{t+1}}{\text { ajexdit }_{t+1}} \times \frac{\text { ajexdit }}{p r c c d_{t} \times t r f d_{t}}\right)$
} 
time-varying. The latter assumption differs slightly from LW15, which assumes that the model parameters are industry-specific. These implementation choices reflect a trade off between parsimony and realism necessitated by the relative sparsity, both in time series and cross-section, of international equity fundamentals data. In the section on robustness tests we describe how relaxing the assumption of dividend payouts being constant in the cross-section affects our model parameters.

\subsection{Sample Selection}

We began with a set of 34 countries whose capital markets and related institutions have been commonly studied in the international asset pricing literature - Australia, Austria, Belgium, Canada, China, Denmark, Finland, France, Germany, Greece, Hong Kong, India, Indonesia, Israel, Italy, Ireland, Japan, Malaysia, Netherlands, New Zealand, Norway, Pakistan, the Philippines, Portugal, Singapore, South Africa, South Korea, Spain, Sweden, Switzerland, Taiwan, Thailand, the United Kingdom, and the U.S. These include the 31 countries examined by Leuz et al. (2003) and the 23 countries recognized to have developed capital markets (e.g., Ang, Hodrick, Xing, and Zhang, 2009; Fama and French, 2012). Because our estimation requires the use of the log of book-to-market multiple and the log of the gross return-on-equity ratio, firms with negative book values are excluded from our analyses.

We impose three sets of filters to mitigate the influence of unusual observations on our estimation and calibration of the paper's model. First, in each country and on each forecast date, we eliminate very small and illiquid firms - any firm belonging to the bottom 2 percent of the cross-section in either market capitalization or liquidity. ${ }^{15}$ Second, we exclude observations whose stock price belongs to the bottom 5 percent of the

\footnotetext{
${ }^{15}$ Following prior research (e.g., LaFond, Lang, and Skaife, 2007), we proxy for a stock's liquidity using the proportion of zero-return days over the prior month. This approximation is necessitated by a lack of a well-populated trading-volume variable in the Compustat Global price files.
} 
cross-section or is trading below 1 unit of the home currency. Third, to further ensure the reliability of the cross-sectionally-estimated coefficients, we impose the requirement that each cross section, after applying the above filters, must have a minimum of 100 observations.

These restrictions, in conjunction with a minimum of 40 months of data, eliminate the following 5 countries from our empirical analyses: Austria, Ireland, New Zealand, Singapore, and Portugal. Thus, the empirical analyses in our paper examine the efficacy of our model-implied ERPs for a set of 29 countries worldwide.

We also take measures to ensure that our data are not corrupted by inconsistencies arising from the use of different currencies to report financial data within a given country. For the eurozone countries that switched currencies following adoption of the euro, we convert all pre-adoption financial data to euro using the conversion rate mandated by the European Central Bank. This translation simply makes the within-country currency amounts comparable pre- and post-euro conversion. For all other occasions where companies switch currencies, we drop the two years surrounding the change. ${ }^{16}$

\subsection{Summary Statistics}

Table 1 summarizes, by country, our data on the model inputs of Eq., (13). It reports time-series averages of the distributional statistics of $b m$ and roe. With the exception of South Korea, all countries on average have (cross-sectional) median $b m$ values that are negative, such that book values tend to be smaller than market values. There is wide variation in the central tendency of $b m$ across countries, ranging from a median $b m$ of 0.11 in South Korea to -1.17 in China. Despite this variation in central tendency, the spread in the distribution appears similar across most countries. In contrast, the (time-series)

\footnotetext{
${ }^{16}$ We set the one-month-ahead returns to missing whenever the given fiscal year's financials are reported in a different currency than the following year's financials. This adjustment affects less than $1 \%$ of the sample.
} 
averages of (cross-sectional) median and mean roe values are relatively uniform across all the countries in our sample.

The last two columns of Table 1 report the initial and final dates for which we have fundamentals and returns data for each country (after imposing the sample selection requirements described above). There is some variation in how early the data begins. For three countries (Canada, Japan, and the U.S.), data became available in the mid- to late-1980s; for most countries data became available in the early- to mid-1990s. For a small handful of countries (Belgium, China, Finland, Greece, Israel, Norway, Pakistan, and the Philippines), data are not available until the 2000s.

Table 2 presents FM coefficients from monthly regressions of one-month-ahead returns $(r)$ on $b m$ and roe, i.e., the time-series mean of the cross-sectionally-estimated coefficients. These two fundamental variables explain between $1 \%$ and almost $5 \%$ of the cross sectional variation in contemporaneous volatility, averaging $2.2 \%{ }^{17}$ Our findings suggest that roe exhibits a stronger association with returns compared to $b m$. The FM coefficient on roe is positive and significant (at the 10-percent level) in 27 of the 29 countries in our sample; on the other hand, the coefficient on $b m$ is significant (at the 10-percent level) for 21 of the 29 countries. These patterns suggest that roe is more reliably and systematically associated with realized returns compared to $\mathrm{bm}$.

Finally, we form the model-implied expected one-month-ahead return proxy on each forecast date using historically estimated FM coefficients. Recall, at the end of each

\footnotetext{
${ }^{17}$ As noted in Lewellen (2015), FM $R^{2}$ is not an indicator of predictive power, but reflects the degree to which the ERP explains contemporaneous variation. To see why, consider the following simple example. Suppose that expected returns are constant for all firms (i.e., no cross-sectional variation), but news has the following structure:

$$
\begin{aligned}
r_{i, t+1} & =e r+\epsilon_{i, t+1} \\
\epsilon_{i, t+1} & =C_{t+1} \times \operatorname{erp}_{i, t}
\end{aligned}
$$

where $C_{t+1}$ is a cross-sectional random variable taking a positive or a negative value with $50 \%$ probability in a given time period. In this case, even though the proxy $\left(e r p_{i, t}\right)$ has no predictive ability, in crosssectional regressions it will completely explain the ex post contemporaneous volatility in realized returns, i.e., $100 \% R^{2}$.
} 
calendar month after the initial 40-month burn-in period, we construct a forecast of one-month-ahead returns by applying the cumulative average of all the cross-sectional coefficients from estimating Eq., (13) to the currently available annual $b m$ and roe.

Table 3 reports the time-series average of the cross-sectional distributional summary statistics for the estimated expected one-month-ahead log returns. We observe substantial within-country variation in the ERP as well as across-country variation in the (crosssectional) mean in the ERP. Comparing the mean expected log return (column 3) to the mean realized log return (column 10) suggests that our ERPs are on average similar to future average realized returns for all the countries.

For ease of interpretation, column (4) reports the mean of expected simple returns $\left(R_{i, t+1}\right)$ implied by our model-implied ERPs. Based on the standard assumption that log returns are conditionally normally distributed, expected simple returns can be constructed as follows:

$$
\hat{\mathbb{E}}_{t}\left[R_{i, t+1}\right]=\exp \left(\hat{\mu}_{i, t}+0.5 \times \hat{\sigma}_{i, t+1}^{2}\right)
$$

where $\hat{\mu}_{i, t}$ is our expected log return estimate, and $\hat{\sigma}_{i, t+1}^{2}$ is an estimate of the expected volatility in log returns based on the average squared daily returns from the prior month scaled by $252 / 12$. Across the 29 countries in our analysis, the cross-sectional mean (median) monthly expected simple returns is $0.99 \%$ (0.91\%) or $12.60 \%(11.43 \%)$ annualized. Though these implied expected simple return estimates are not the main focus of the paper, we will return to them later in our robustness tests to assess its relative performance to factor-based estimates of expected simple returns.

\subsection{Cross-Sectional Validation Tests}

We next turn to validating the model-implied ERPs and assessing their reliability across worldwide markets. We first examine how the proxies, on average, are associated with future returns. We then assess performance against standard factor-model-based 
proxies.

\subsubsection{Regression Based Tests}

Our primary test for assessing the reliability of our ERPs is the standard regressionbased test as employed by, for example, Lewellen (2015) and Lyle and Wang (2015). In particular, we separately estimate for each country cross-sectional predictive regressions of 1-month-ahead $r$ on our ERPs:

$$
r_{i, t+1}=\delta_{0}+\delta_{1} \mathbb{E}_{t}\left[r_{i, t+1}\right]+w_{i, t+1}
$$

True expected returns implies $\delta_{0}=0$ and $\delta_{1}=1$. In particular, having a slope coefficient close to 1 suggests that the magnitudes of the cross-sectional differences in the ERP are informative of the magnitude of differences in expected returns, which facilitate inferences in regression settings. More generally, positive and significant $\delta_{1}$ coefficients imply positive return sorting ability on average. To reduce the influence of unusually large values in our estimates, we winsorize the expected return measures at the top and bottom 1 percent.

Table 4 reports FM regression estimates of Eq., (15) for the 29 countries in the sample. The results in this table indicate that the model-implied ERPs strongly and significantly predict realized returns for a vast majority of the countries. Coefficients on expected returns (the "predictive slope coefficient") are statistically significant at the 5-percent and 10-percent levels for 24 and 26 of the 29 countries, respectively. Greece, Pakistan, and South Africa's predictive slope coefficients do not differ significantly from 0 at the $10 \%$ level; in the case of Pakistan, the slope is also indistinguishable from 1.

The average slope coefficient across the 29 countries is 1.05. Based on the F-test for the null hypothesis that the slope is equal to 1 (reported in the last row of Table 4), we reject the null for only 9 (10) of the 29 countries at the 10-percent (5-percent) level. 
Furthermore, we fail to reject the null that the constant term is equal to 0 at the 5 -percent level for all but 2 countries in our sample. In the aggregate, these regression-based test results suggest that our accounting-based ERPs line up well with true expected returns and are reliably associated with the cross section of future returns across international markets. $^{18}$

\subsubsection{Portfolio Sort Tests}

We supplement the above parametric return regression tests with a portfolio-level analysis. To conduct these non-parametric tests, we construct equal-weighted portfolios at the end of each calendar month based on the quintile rankings of the ex ante ERP, and summarize the average 1-month-ahead returns realized by each portfolio. Our choice of quintile portfolios is intended to ensure that, for any given country on any given month, there are at least 20 stocks in each portfolio.

Table 5 provides further evidence that, consistent with the regression tests of Table 4, the model-implied proxies exhibit significant ability to predict the cross-section of future returns. We document in column (6) significant average spreads between the top and bottom quintile portfolios for 24 countries. Though these results are statistically slightly weaker, they are broadly consistent with the regression-based tests. In fact, the portfolio sorts are robust enough that for the majority of the countries (20), even the spread between the portfolio median returns, reported in column (7), are statistically significant.

On the basis of these results we conclude that reliable firm-level expected stock returns that are applicable to worldwide markets can be constructed with a linear combination of $b m$ and roe. These findings also demonstrate, consistent with Lewellen (2015), that firm-level ERPs obtained from FM regressions exhibit strong cross-sectional predictive

\footnotetext{
${ }^{18}$ In untabulated robustness tests, we find that winsorizing the inputs at the top and bottom 1 percent of each cross section yields ERPs that produce virtually identical results.
} 
properties.

\subsection{Robustness Tests}

In this section we assess the performance of factor-model-based ERPs to contextualize our main findings. We also describe how relaxing the assumption of dividend payouts being constant in the cross section affects our model parameters. Finally, we discuss untabulated analyses on the sensitivity of the ERPs to variations in the training sample period as well as performance based on alternative evaluative frameworks.

\subsubsection{Factor-Based Estimates}

To contextualize our main empirical results, we assess the performance of firm-level ERPs derived from the global and regional four-factor models described in Fama and French (2012). These are global and regional versions of the Fama and French (1993) three-factor model augmented with the momentum factor, but calculated based on portfolios that encompass 23 countries in four regions: Australia, Austria, Belgium, Canada, Denmark, Finland, France, Germany, Greece, Hong Kong, Ireland, Italy, Japan, the Netherlands, New Zealand, Norway, Portugal, Singapore, Spain, Switzerland, Sweden, U.K., and U.S. The monthly global and regional factor returns are obtained from Ken French's data library. ${ }^{19}$

At the end of each calendar month $(t)$, one-month-ahead factor-based ERPs for a firm (i) are constructed as follows:

$$
\begin{aligned}
\hat{\mathbb{E}}_{t}\left[r_{i, t+1}\right]= & r f_{t+1}+\hat{\gamma}_{i, R M R F} \hat{\mathbb{E}}_{t}\left[R M R F_{t+1}\right]+\hat{\gamma}_{i, S M B} \hat{\mathbb{E}}_{t}\left[S M B_{t+1}\right] \\
& +\hat{\gamma}_{i, H M L} \hat{\mathbb{E}}_{t}\left[H M L_{t+1}\right]+\hat{\gamma}_{i, W M L} \hat{\mathbb{E}}_{t}\left[W M L_{t+1}\right]
\end{aligned}
$$

\footnotetext{
${ }^{19}$ http://mba.tuck.dartmouth.edu/pages/faculty/ken.french/data_library.html
} 
Here $\hat{\mathbb{E}}_{t}\left[R M R F_{t+1}\right], \hat{\mathbb{E}}_{t}\left[S M B_{t+1}\right], \hat{\mathbb{E}}_{t}\left[H M L_{t+1}\right]$, and $\hat{\mathbb{E}}_{t}\left[W M L_{t+1}\right]$ represent the expected global or regional market, size, value, and momentum factor returns, respectively, which we estimate based on the trailing average 40 -month realized factor returns. $\hat{\gamma}_{i, j}$ represents the factor $j$ loadings for a firm, estimated in time-series for each firm $i$ using monthly stock and factor returns over the 40 months prior to the forecast date. Risk-free rates are proxied by US treasury yields. Because the global and regional factors are calculated using US-Dollar-denominated returns, for consistency in this exercise we convert all price series to US Dollars and compute US-Dollar-denominated returns for all firms in our sample.

Because these factor-based models yield expected simple returns, we compare them against our model-implied estimate of expected simple returns following equation (14). Table 6 reports the results of regression-based tests for the global- and regional-factorbased ERPs for the 29 countries in our sample alongside the results of the model-implied simple ERPs. To facilitate comparisons, we use a common set of firm-year observations for which all three ERPs are available. Like our results in Table 4, the model-implied simple ERPs perform very well across all 29 countries. In fact, the predictive slope coefficient is positive and significant for all 29 countries. In striking contrast, with the exception of one country, the global- and regional-factor-based ERPs do not exhibit out-of-sample return predictability. The exception is in Pakistan, for which the global four-factor model exhibits a modest slope coefficient of 0.2548 that is significant at the $10 \%$ level. For the remaining countries the slope coefficients are either significantly negative (4 countries) or indistinguishable from zero at the 10-percent level.

We also consider the recent Fama and French (2014) five-factor model, which augments Fama and French (1993)'s original three-factor model with a profitability factor and an investment factor. Fama and French (2014) show that this expanded model better explains the cross section of average returns in-sample compared to the three-factor 
model. We complement their findings by assessing the out-of-sample performance of five-factor-based ERPs, reported in the second-to-last row of Table 6. Our regressionbased tests of this model are restricted to the U.S. since profitability and investment factor returns are not available globally. As with the four-factor model, we find that this expanded model does not produce ERPs that are robustly associated with future returns. We document a negative but insignificant slope coefficient.

Finally, we consider a variation of the new factor model that incorporates only the market, value, and profitability factors, representing the factor-based counterpart to our paper's characteristic-based model. The out-of-sample performance, reported in the last row of Table 6, continues to be poor, as the proxy exhibits a negative and significant slope coefficient at the 10-percent level.

Juxtaposed against the performance of our model-implied simple ERPs, these results overall show that the out-of-sample cross-sectional predictive ability of our model-implied ERPs dramatically outperform that of alternative factors-based proxies. We note that findings need not necessarily invalidate the factor models per se, but could be consistent with the possibility that firm characteristics better capture time-varying factor loadings and premiums (e.g., Cochrane, 2011), which are notoriously difficult to estimate (Fama and French, 1997). This evidence is also consistent with and generalizes the findings of LW15 across international markets and accounting systems, broadly echoing the views of Campbell, Polk, and Vuolteenaho (2010) that accounting information is useful in explaining firm level expected rate of returns. More strongly, our evidence suggest that accounting-based valuation models provide a unifying framework for estimating firm-level expected rates of returns around the world. 


\subsubsection{Dividend Payout Variation}

We also analytically and empirically examine how the coefficients A2 and A3 embedded in (13) depend on the dividend payout ratio. We show in the Appendix that the loading on $b m$ and roe is expected to increase with the payout ratio. ${ }^{20}$ We test these formal predictions empirically by estimating the following contemporaneous Fama-MacBeth regression:

$$
\begin{aligned}
r_{i, t+1}= & \beta_{1}+\beta_{2} \times \text { bm }_{i, t}+\beta_{3} \times \text { roe }_{i, t+1}+\beta_{4} \times \text { payout }_{i, t+1} \\
& +\beta_{5} \times \text { bm }_{i, t} \times \text { payout }_{i, t+1}+\beta_{6} \times \text { roe }_{i, t+1} \times \text { payout }_{i, t+1}+\zeta_{i, t+1},
\end{aligned}
$$

where payout $_{i, t+1}=$ Dividend $_{i, t+1} /$ Book $_{i, t+1}$, which is consistent with the model presented in the paper. The empirical results, reported in Table 7, largely support the theoretical predictions. The coefficients on the interactions of $b m$ and roe with payout are positive and statistically significant in a large number of countries. Specifically, the coefficient on $b m \times$ payout is positive in all but one of the countries in our sample, and is statistically significant at the 10-percent level in 23 countries. The coefficient on roe $\times$ payout is positive for all but two countries; however, the statistical significance of this coefficient is less strong, with 14 being significant at the 10-percent level. We note that the statistical significance of these results are likely in part attenuated by noise in the dividend data. Our discussions with the $\mathrm{S} \& \mathrm{P}$ reveals that there is a variation in the accuracy with which Compustat Global captures dividends across countries. Nevertheless, these estimates are broadly consistent with the model's predictions that firms with higher future payouts should produce higher loadings.

\footnotetext{
${ }^{20}$ This is true so long as the persistence of expected returns is positive and is greater than the persistence of expected profitability, i.e., $\kappa>\omega$. Indeed, the average coefficients on $b m$ and roe across countries implies persistence parameters of $\kappa \approx 0.98$ and $\omega \approx 0.88$, values that are consistent with those documented in Lyle and Wang (2015).
} 


\subsubsection{Sensitivity to Training Sample Window}

In untabulated tests we also assess the sensitivity of our proxies to the choice of the burn-in period. Our baseline results use the first 40 months of data as the training sample before constructing ERPs and conducting out-of-sample tests. Our choice of 40 months, which we view to be a relatively short training period, was motivated by the relatively short sample of available data in certain countries (e.g., Israel and Pakistan).

We vary the training window to include 30 and 50 months and for nearly all countries, these variations in the training sample period do not affect our inferences. For Finland and the Netherlands, widening the training sample and reducing the testing window reduces the statistical significance slightly, with t-statistics of 1.56 and 1.33, respectively. Reducing the training window to 30 months marginally affects one country - Switzerlandpredictive coefficients remain positive and large in magnitude with borderline t-statistics of 1.63. Overall, however, our main findings on the association with the cross section of future returns across countries are not very sensitive to the training window period.

\subsubsection{Association with Risk Proxies}

This paper focuses on expected returns as a statistical construct, and in doing so we abstract away from the market efficiency debate. If one subscribes to market efficiency, expected returns should only be a function of sensitivities or exposures to risk factors. Conversely, in a behavioral framework, expected returns can also be a function of other non-risk-related behavioral factors.

However, in unreported tests, we find that our expected simple return proxies are significantly associated with traditional measures of risk. In particular, we find positive and significant associations (at the $1 \%$ level) with market beta and log book-to-market, and negative and significant associations (at the $1 \%$ level) with size (i.e., log of market capitalization) and liquidity (i.e., percent of zero-return days over the prior month). Note 
that while the correlation with book-to-market is not surprising, its inclusion ensures that the correlation with alternative risk proxies are not driven by it. The positive association with market beta is also notable, suggesting that the noisiness in estimating factor risk premiums plays an important role in the poor performance of factor-based ERPs. These findings overall suggest that our model-implied ERPs are also validated based on the alternative evaluative framework that is adopted in the literature (e.g., Botosan et al., 2011), i.e., based on ERPs' associations with commonly-accepted risk proxies.

\section{Accounting Quality: Implications and Tests}

While the empirical evidence presented above establishes the usefulness of accounting information in estimating expected returns across the world, accounting systems, and the quality of the information they produce, can significantly vary from one market and institutional setting to another. This section analyzes, both analytically and empirically, how our model of expected returns is affected by the quality of accounting information provided to investors.

\subsection{Model Setup and Key Implication}

To investigate this issue analytically, we extend the baseline model of expected returns to a setting where information is imperfect. To introduce the concept of imperfections in the accounting system vis-à-vis return prediction, we assume that investors do not directly observe expected growth in book value, $h_{t}$, but learn about it dynamically over time using realized accounting reports. ${ }^{21}$

\footnotetext{
${ }^{21}$ Unlike related studies in the literature (e.g., van Binsbergen and Koijen, 2010), we do not assume that investors need to filter expected returns; our rationale is that since investors set prices, given their expectations of book growth they must also set expected market returns. Our setting is thus closely related to that of Pástor and Veronesi (2003, 2006), except that we do not assume an exogenous discount factor.
} 
In the spirit of Dechow, Ge, and Schrand (2010), we assume that investors observe financial reports of book growth, $g_{b, t+1}$, which reflects both "true" firm performance $\left(g_{\text {true }, t+1}\right)$ and noise $\left(\xi_{t+1}^{r}\right)$ from the accounting system:

$$
\begin{aligned}
g_{b, t+1} & =g_{\text {true }, t+1}+\xi_{t+1}^{r}, \text { and } \\
g_{\text {true }, t+1} & =h_{t}+\xi_{t+1}^{\text {true }} .
\end{aligned}
$$

It follows that observed reports of book growth $\left(g_{b, t+1}\right)$ have two sources of noise: (1) true "fundamental" or "innate" noise $\left(\xi_{t+1}^{\text {true }}\right)$ and $(2)$ measurement errors from the accounting system $\left(\xi_{t+1}^{r}\right)$. We assume that the noise in the reports is captured by two independent error terms, $\xi_{t+1}^{t r u e} \sim N\left(0, \sigma^{2}\right)$ and $\xi_{t+1}^{r} \sim N\left(0, \sigma_{r}^{2}\right){ }^{22}$ Mapping this back into the assumptions about growth in book value (3), we have:

$$
g_{b, t+1}=h_{t}+\xi_{t+1}^{t r u e}+\xi_{t+1}^{r}
$$

Since investors observe only realized growth in book values, they form expectations of book growth by making inferences (or learning) about the unobserved $h_{t}$ using relevant information to optimally update their beliefs over time. We denote $f_{t}=\mathbb{E}\left[h_{t} \mid \mathcal{F}_{t}\right]$ as investors' beliefs about mean book growth given $\mathcal{F}_{t}$, where $\mathcal{F}_{t}=\left\{g_{b, \tau}\right\}_{\tau \in\{0,1, \ldots, t\}}$ represents the history of accounting reports available to investors. Assuming that $h_{t}$ is also conditionally Gaussian, it can be shown that investors' optimal dynamic updates to their beliefs take the following form:

$$
f_{t+1}=\mu+\omega\left(f_{t}-\mu\right)+\frac{\omega v_{t}}{\sigma^{2}+\sigma_{r}^{2}+v_{t}}\left(g_{b, t+1}-f_{t}\right)
$$

where $v_{t}=\mathbb{E}\left[\left(f_{t}-\mathbb{E}\left[f_{t} \mid \mathcal{F}_{t}\right]\right)^{2} \mid \mathcal{F}_{t}\right]$ is the conditional variance of $f_{t}$ with respect to investors

\footnotetext{
${ }^{22}$ While the assumption of Gaussian error terms is common and somewhat restrictive, the assumption of independence is without loss of generality.
} 
filtration $\mathcal{F}_{t}$, or the dispersion in investors' prior beliefs; $\sigma_{h}^{2}$ is the conditional variance of $h_{t} ;$ and $v_{t+1}=\omega^{2} v_{t}+\sigma_{h}^{2}-\frac{\omega^{2} v_{t}^{2}}{\sigma^{2}+\sigma_{r}^{2}+v_{t}} \cdot{ }^{23}$

Using this updating rule, we show in the Appendix that when the accounting system is imperfect, expected stock returns are a linear combination of $b m$ and roe:

$$
\mathbb{E}\left[r_{t+1} \mid \mathcal{F}_{t}\right]=C_{1}(t)+C_{2}(t) f_{t-1}+C_{3} b m_{t}+C_{4}(t) \text { roe }_{t}
$$

in which the coefficient on roe takes the following form

$$
C_{4}(t)=A_{3} \frac{\omega v_{t-1}}{\sigma^{2}+\sigma_{r}^{2}+v_{t-1}} .
$$

This model provides the key insight that, all else equal, better accounting information quality elevates the importance of roe in forecasting future returns. Specifically, conditional on the dispersion of investors' prior beliefs $\left(v_{t-1}\right)$, the volatility in the underlying fundamentals $\left(\sigma^{2}\right)$, and the persistence in expected returns and expected roe, the coefficient on roe is increasing with accounting information quality (or decreasing in $\sigma_{r}^{2}$ ).

The above analytical approach also allows a reconciliation of our model to the various alternative firm characteristics and signals (e.g., valuation ratios and accounting data) that relate to future stock returns. In particular, generalizing the above to include multiple information sources in investors' information set, if a signal systematically forecasts future payoffs (i.e., future roe), conditional on $b m$, it follows that such a variable is also systematically associated with expected returns. This insight suggests that the empirical approach used by Ou and Penman (1989), coupled with our parsimonious model, may offer an exciting area of potential future research in accounting and characteristic-based asset pricing.

\footnotetext{
${ }^{23}$ This follows directly from Theorem 13.4 of Liptser and Shiryaev (1977).
} 


\subsection{Empirical Tests}

We proceed to empirically test the prediction that, all else equal, higher-quality accounting information leads investors to place greater weight on roe. Accounting information quality, specifically the variance in measurement errors in the context of the model above, is difficult to measure. We adopt the methodology of Leuz et al. (2003), which creates a composite country-level measure of accounting quality by averaging a given country's rankings across four dimensions.

The first two dimensions of information quality capture the extent to which firms in a given country engage in earnings smoothing. The first earnings-smoothing measure (Variability) takes each country's median ratio of firm-level standard deviation of operating earnings divided by the firm-level standard deviation of cash-flow from operations, and ranks these median ratios across countries in descending order. A lower ratio implies a greater degree of earnings smoothing, and hence lower earnings quality, resulting in a higher rank. The second earnings-smoothing measure (Correlation) takes the magnitude of the contemporaneous correlation between changes in accounting accruals and changes in operating cash flows in each country, and ranks this correlation across countries in ascending order. This correlation is estimated by pooling all firm-years within a country; a greater magnitude implies greater earnings smoothing and lower earnings quality, resulting in a higher rank.

The third and fourth dimensions of information quality proxy for the extent of the use of accruals to manage earnings in a given country. The third measure (Accruals Magnitude) takes the median of the ratio between the absolute value of firm accruals and the absolute value of firm cash-flow from operations in a given country, and ranks this measure across countries in ascending order. A higher median ratio implies a greater use of accruals to manage earnings, and lower earnings quality, resulting in a higher rank. The fourth and final dimension of poor information quality (Small Loss Avoidance) takes the 
ratio between instances of small profits and instances of small losses, calculated by pooling all firm-years within a country, and ranks the measure across countries in ascending order. Small profits and small losses are calculated using earnings scaled by total assets, where small losses are defined as in the range $[-0.01,0)$ and small profits are defined as in the range $[0.00,0.01]$. A higher ratio implies greater use of managerial discretion in managing earnings, and lower earnings quality, resulting in a higher rank.

Our main empirical test, reported in Table 8, explores cross-country variations between this proxy, Poor Information Quality, and the median roe coefficient, generated from monthly regressions of Eq., (13). Column (1) of the table reports OLS estimates of regressions of each country's median roe coefficient on its Poor Information Quality measure and a control for the size of each country's equity market. ${ }^{24}$ The rationale for such a control is to address the "all else equal" aspect of the theoretical predictions. Holding accounting information quality constant, the presence of more of information intermediaries may reduce the importance of roe. Consistent with this intuition, our result shows a negative and significant coefficient on market size. Moreover, consistent with the model predictions, we report a negative coefficient on Poor Information Quality, but it is not statistically significant. ${ }^{25}$

We interpret the lack of significance in Poor Information Quality as, at least in part, a result of errors in measuring countries' accounting systems' measurement error variances - the underlying theoretical variable of interest - which is consistent with the coefficient's attenuation to 0 . We resolve this issue empirically by using an instrumentalvariables approach to identify the effect of information quality on the importance of roe.

Our instruments capture the quality of governance institutions in a given country. Our

\footnotetext{
${ }^{24}$ Specifically, we take the $\log$ of the median total market capitalization over the relevant time frame for a given country.

${ }^{25}$ These results exclude Greece, Pakistan, and South Africa, for which the model does not generate reliable proxies. Taiwan is also excluded because information on the strength and quality of its governance institutions is unavailable.
} 
identifying assumption is that the strength of such institutions affects the importance of roe in forecasting future returns only by improving the information quality produced by firms in equity markets. Our instrument, Quality of Governance Institutions, is constructed using data from the World Bank's Worldwide Governance Indicators project, which compiles five metrics on countries' governance institutions. ${ }^{26}$ Rule of Law captures perceptions of the quality of contract enforcement, property rights, and the courts; Accountability captures perceptions of the extent to which citizens have the ability to exert their voices and influence to create accountability in society, including freedom to select their government and the presence of a free media; Political Stability measures perceptions of the likelihood of political instability; Government Effectiveness captures perceptions of the quality of public services and the robustness of the policy formulation process; and Control of Corruption captures perceptions of the extent to which public power is exercised for private benefits. We take the median value of each variable over the relevant time frame for each country and then standardize each measure using the crosssection of countries. Our final country-level variable, Quality of Governance Institutions, is the simple average of the five standardized governance measures.

Columns (2) and (3) report the first- and second-stage results, respectively, of an instrumental-variables estimation in which we instrument Poor Information Quality with Quality of Governance Institutions. The first-stage estimation results suggest that higherquality or stronger governance institutions in a country are significantly associated (at the $1 \%$ level) with higher-quality accounting information, consistent with economic intuition. In the second stage we find that, all else equal, better earnings quality increases the importance of roe in forecasting returns. Specifically, improving a country's earnings-quality rank by 1 unit increases the roe coefficient by about 0.001, representing an economically significant increase of approximately 10 percent for the median country. Consistent with

\footnotetext{
${ }^{26}$ http://info.worldbank.org/governance/wgi/index.aspx\#home
} 
measurement errors influencing the OLS results, the magnitude of the coefficient in the instrumental-variables specifications is substantially larger compared to the baseline OLS specification. Finally, the last column of the table reports the reduced-form OLS estimates from regressing the median roe coefficients on the governance-quality variable and the market size control. Consistent with our instrumental-variables estimates, these results show that stronger and higher-quality governance institutions elevate the importance of roe in forecasting returns.

Table 9 provides further analyses of the impact of information quality on the roe coefficient by examining the four different dimensions of Poor Information Quality separately. Broadly speaking, the results in this table are consistent with those in Table 8. However, whereas results using Variability are substantially, Accruals Magnitude, in contrast, produces the strongest results. Overall, these findings as consistent with the theoretical model and with the intuition that roe plays a reduced role in forecasting returns when accounting information is poor.

\section{Conclusion}

We show that, under fairly general assumptions, expected returns is related to $\mathrm{bm}$ and roe. This parsimonious linear relation is not only theoretically applicable to various accounting systems, but also supported empirically: the model-implied expected return proxies (ERPs) line up well with true expected returns across international markets. Our work promotes an accounting-fundamentals approach to expected returns, and contributes to the stream of empirical studies devoted to developing the estimation of, and understanding the behavior of, expected returns. It also provides a practical tool that can be used to analyze investment choices in international equity contexts.

This tractable model not only performs well empirically but can easily incorporate 
and generate analytical predictions that are not possible in traditional factor-based or ICC models. In particular, our analytical work in integrating the model of expected returns to a dynamic information setting allows for an analysis of how characteristics of accounting systems - specifically the quality of accounting information produced - affects the inference of expected returns. This extension also allows for a reconciliation with and incorporation of alternative forecasters, a fruitful extension of our work for future research. 


\section{References}

Ang, A., R. J. Hodrick, Y. Xing, and X. Zhang (2009). High idiosyncratic volatility and low returns: International and further U.S. evidence. Journal of Financial Economics $91(1), 1-23$.

Angrist, J. D. and J. Pischke (2008). Mostly harmless econometrics: An empiricist's companion. New Jersey: Princeton University Press.

Banz, R. W. (1981). The relationship between return and market value of common stocks. Journal of Financial Economics 9(1), 3-18.

Beaver, W. H. (1970). The Time Series Behavior of Earnings. Journal of Accounting Research 8(May), 62-99.

Bernard, V. L. and J. K. Thomas (1990). Evidence that stick prices do not fully reflect the implications of current earnings for future earnings. Journal of Accounting and Economics 13, 305-340.

Botosan, C. (1997). Disclosure level and the cost of equity capital. The Accounting Review 72(3), 323-349.

Botosan, C. and M. Plumlee (2005). Assessing alternative proxies for the expected risk premium. The Accounting Review 80(1), 21-53.

Botosan, C., M. Plumlee, and H. Wen (2011). The relation between expected returns, realized returns, and firm risk characteristics. Contemporary Accounting Research 28(4), $1085-1122$.

Bushman, R. M. and J. D. Piotroski (2006). Financial reporting incentives for conservative accounting: The influence of legal and political institutions. Journal of Accounting and Economics 42(1), 107-148.

Campbell, J. (1991). A variance decomposition for stock returns. The Economic Journal 101(405), 157-179.

Campbell, J. Y., C. Polk, and T. Vuolteenaho (2010). Growth or glamour? Fundamentals and systematic risk in stock returns. Review of Financial Studies, 305-344.

Chen, H., J. Z. Chen, G. J. Lobo, and Y. Wang (2011). Effects of audit quality on earnings management and cost of equity capital: Evidence from China. Contemporary Accounting Research 28(3), 892-925.

Claus, J. and J. Thomas (2001). Equity premia as low as three percent? evidence from analysts' earnings forecasts from domestic and international stock markets. Journal of Finance 56(5), 1629 - 1666. 
Cochrane, J. (2011). Presidential address: Discount rates. Journal of Finance 66(4), $1047-1108$.

Daniel, K., M. Grinblatt, S. Titman, and R. Wermers (1997). Measuring mutual fund performance with characteristic-based benchmarks. The Journal of Finance 52(3), $1035-1058$.

Dechow, P., W. Ge, and C. Schrand (2010, December). Understanding earnings quality: A review of the proxies, their determinants and their consequences. Journal of Accounting and Economics 50(2-3), 344-401.

Easton, P. and S. Monahan (2005). An evaluation of accounting-based measures of expected returns. The Accounting Review 80(2), 501.

Easton, P. D. (2004). Pe ratios, peg ratios, and estimating the implied expected rate of return on equity capital. The Accounting Review 79, 73 - 96.

Fama, E. and K. French (1992). The cross-section of expected stock returns. The Journal of Finance 47(2), 427-465.

Fama, E. and K. French (1997). Industry costs of equity. Journal of Financial Economics 43(2), 153-193.

Fama, E. F. and K. R. French (1993). Common risk factors in the returns on stocks and bonds. Journal of financial economics 33(1), 3-56.

Fama, E. F. and K. R. French (2008). Dissecting anomalies. Journal of Finance 63(4), $1653-1678$.

Fama, E. F. and K. R. French (2012). Size, value, and momentum in international stock returns. Journal of Financial Economics 105(3), 457-472.

Fama, E. F. and K. R. French (2014). A five-factor asset pricing model. Journal of Financial Economics.

Fama, E. F. and J. D. MacBeth (1973). Risk, return, and equilibrium: Empirical tests. The Journal of Political Economy, 607-636.

Feltham, G. A. and J. A. Ohlson (1995). Valuation and clean surplus accounting for operating and financial activities. Contemporary Accounting Research 11(2), 689-731.

Gebhardt, W. R., C. M. C. Lee, and B. Swaminathan (2001). Toward an implied cost of capital. Journal of Accounting Research 39(1), 135-176.

Gode, D. and P. Mohanram (2003). Inferring the cost of capital using the Ohlson-Juettner model. Review of Accounting Studies 8(4), 399-431. 
Green, J., J. R. M. Hand, and X. F. Zhang (2013). The supraview of return predictive signals. Rev. Account. Stud. 18(3), 692-730.

Hail, L. and C. Leuz (2006, June). International differences in the cost of equity capital: Do legal institutions and securities regulation matter? Journal of Accounting Research 44(3), 485-531.

Hamilton, J. D. (1994). Time Series Analysis. New Jersey: Prentice Hall.

Haugen, R. A. and N. L. Baker (1996). Commonality in the determinants of expected stock returns. Journal of Financial Economics 41(3), 401-439.

Healy, P., G. Serafeim, S. Srinivasan, and G. Yu (2014). Market competition, earnings management, and persistence in accounting profitability around the world. Review of Accounting Studies 19(4), 1-28.

Hou, K., G. A. Karolyi, and B.-C. Kho (2011). What factors drive global stock returns? Review of Financial Studies 24(8), 2527-2574.

Jegadeesh, N., N. Jegadeesh, S. Titman, and S. Titman (1993). Returns to buying winners and selling losers: Implications for stock market efficiency. Journal of Finance 48(1), 65 .

LaFond, R., M. Lang, and H. A. Skaife (2007). Earnings smoothing, governance and liquidity: international evidence. Massachusetts Institute of Technology Working Paper.

Lambert, R., C. Leuz, and R. E. Verrecchia (2007). Accounting information, disclosure, and the cost of capital. Journal of Accounting Research 45(2), 385-420.

Lee, C., D. Ng, and B. Swaminathan (2009). Testing international asset pricing models using implied costs of capital. Journal of Financial and Quantitative Analysis 44(2), 307.

Lee, C., E. So, and C. C. Wang (2014). Evaluating implied cost of capital estimates. Stanford University Working Paper.

Leuz, C., D. Nanda, and P. D. Wysocki (2003). Earnings management and investor protection: an international comparison. Journal of Financial Economics 69(3), 505527.

Lewellen, J. (2015). The cross section of expected stock returns. Forthcoming in Critical Finance Review.

Link, B. (2012). The struggle for a common interim reporting frequency regime in Europe. Accounting in Europe 9(2), 191-226.

Liptser, R. and A. Shiryaev (1977). Statistics of random processes: Applications, Volume 2. Springer Verlag. 
Lyle, M. R., J. L. Callen, and R. J. Elliott (2013). Dynamic risk, accounting-based valuation and firm fundamentals. Review of Accounting Studies 18(4), 899-929.

Lyle, M. R. and C. C. Wang (2015). The cross section of expected holding period returns and their dynamics: A present value approach. Journal of Financial Economics 16(3), $505-525$.

Novy-Marx, R. (2013). The other side of value: The gross profitability premium. Journal of Financial Economics 108(1), 1-28.

Ohlson, J. (1995). Earnings, book values, and dividends in equity valuation. Contemporary Accounting Research 11(2), 661-687.

Ou, J. A. and S. H. Penman (1989). Financial statement analysis and the prediction of stock returns. Journal of Accounting and Economics 11(4), 295-329.

Pástor, L. and R. Stambaugh (2012). Are stocks really less volatile in the long run? Journal of Finance 67(2), 431-478.

Pástor, L. and P. Veronesi (2003). Stock valuation and learning about profitability. Journal of Finance 58(5), 1749-1790.

Pástor, L. and P. Veronesi (2006). Was there a Nasdaq bubble in the late 1990s? Journal of Financial Economics 81(1), 61-100.

Pástor, L. and P. Veronesi (2009). Learning in financial markets. Annual Review of Financial Economics 1(1), 361-381.

Penman, S., F. Reggiani, S. Richardson, and I. Tuna (2013). A characteristic model for asset pricing and risky value slides. Working Paper.

Penman, S. H. (1991). An evaluation of accounting rate-of-return. Journal of Accounting, Auditing \& Finance 6(2), 233-255.

Piotroski, J. D. (2000). Value investing: The use of historical financial statement information to separate winners from losers. Journal of Accounting Research 38, 1-41.

Rosenberg, B., K. Reid, and R. Lanstein (1985). Persuasive evidence of market inefficiency. The Journal of Portfolio Management 11(3), 9-16.

Sharpe, W. F. (1964). Capital asset prices: A theory of market equilibrium under conditions of risk. The Journal of Finance 19(3), 425-442.

Sloan, R. (1996). Do stock prices fully reflect information in accruals and cash flows about future earnings? Accounting Review 71 (3), 289-315.

van Binsbergen, J. and R. Koijen (2010). Predictive regressions: A present-value approach. Journal of Finance 65(4), 1439-1471. 
Vuolteenaho, T. (2002). What drives firm-level stock returns? Journal of Finance 57(1), $233-264$.

Wang, C. C. (2015). Measurement errors of expected return proxies and the implied cost of capital. Working Paper. 


\section{Appendix}

\section{Book-to-Market Derivation}

We begin with the definitions of gross realized market and book equity growth:

$$
\begin{aligned}
G_{m, t+1} & =\frac{M_{t+1}}{M_{t}}, \\
G_{b, t+1} & =\frac{B_{t+1}}{B_{t}},
\end{aligned}
$$

where $M_{t}$ and $B_{t}$ are the market value and book value of equity at the end of period $t$. These lead to the following definition for the book-to-market ratio:

$$
\frac{B_{t}}{M_{t}}=\frac{G_{b, t+1}^{-1} B_{t+1}}{G_{m, t+1}^{-1} M_{t+1}} .
$$

Taking logs of both sides of (A.3), the log book-to-market ratio $\left(b m_{t}\right)$ can be written as

$$
b m_{t}=b m_{t+1}+g_{m, t+1}-g_{b, t+1},
$$

where $g_{m, t+1}=\log \left(G_{t+1}\right)$ and $g_{b, t+1}=\log \left(G_{B, t+1}\right)$. Iterating (A.4) forward obtains

$$
b m_{t+1}=b m_{t+2}+g_{m, t+2}-g_{b, t+2}
$$

which implies that (A.4) can be expressed as

$$
b m_{t}=b m_{t+2}+g_{m, t+2}-g_{b, t+2}+g_{m, t+1}-g_{b, t+1} .
$$

Thus, progressive substitution yields the following expression of the log book-to-market ratio:

$$
b m_{t}=b m_{t+\tau}+\sum_{i=1}^{\tau}\left[g_{m, t+i}-g_{b, t+i}\right]
$$


Taking conditional expectations on both sides with respect to information known at time $t$, we obtain

$$
b m_{t}=\mathbb{E}_{t}\left[b m_{t+\tau}\right]+\sum_{i=1}^{\tau} \mathbb{E}_{t}\left[g_{m, t+i}-g_{b, t+i}\right],
$$

and letting $\tau \rightarrow \infty$ yields

$$
b m_{t}=\lim _{\tau \rightarrow \infty} \mathbb{E}_{t}\left[b m_{t+\tau}\right]+\sum_{i=1}^{\infty} \mathbb{E}_{t}\left[g_{m, t+i}-g_{b, t+i}\right]
$$

Under our stationary assumption on $b m$, i.e., $\lim _{\tau \rightarrow \infty} \mathbb{E}_{t}\left[b m_{t+\tau}\right]=\overline{b m}$, we simplify the above to

$$
b m_{t}=\overline{b m}+\sum_{i=1}^{\infty} \mathbb{E}_{t}\left[g_{m, t+i}-g_{b, t+i}\right]
$$

Finally, under the assumption that expected market growth (denoted $\mu_{t}=E_{t}\left[g_{m, t+1}\right]$ ) and expected book growth (denoted $h_{t}=E_{t}\left[g_{b, t+1}\right]$ ) follow $\mathrm{AR}(1)$ processes, i.e.,

$$
\begin{aligned}
\mu_{t+1} & =\mu+\kappa\left(\mu_{t}-\mu\right)+\xi_{t+1}, \text { and } \\
h_{t+1} & =\mu+\omega\left(h_{t}-\mu\right)+\epsilon_{t+1},
\end{aligned}
$$

we can rewrite (A.10) as

$$
\begin{aligned}
b m_{t} & =\overline{b m}+\sum_{i=1}^{\infty}\left(\mathbb{E}_{t}\left[\mu_{t+i-1}\right]-\mathbb{E}_{t}\left[h_{t+i-1}\right]\right) \\
& =\overline{b m}+\sum_{i=1}^{\infty}\left(\kappa^{i-1}\left(\mu_{t}-\mu\right)-\omega^{i-1}\left(h_{t}-\mu\right)\right) .
\end{aligned}
$$

Solving the infinite sum yields equation (8) in the text:

$$
b m_{t}=\overline{b m}+\frac{1}{1-\kappa}\left(\mu_{t}-\mu\right)-\frac{1}{1-\omega}\left(h_{t}-\mu\right) .
$$




\section{Expected Returns Derivation}

This subsection describes in detail the derivation of expected returns as a function of $b m$ and expected roe. We begin with the observation that expected stock returns are given by:

$$
\mathbb{E}_{t}\left[r_{t+1}\right]=\mu_{t}+\mathbb{E}_{t}\left[\log \left(1+\frac{D_{t+1}}{M_{t+1}}\right)\right]
$$

We follow Pástor and Veronesi (2003) and assume that dividends are proportional to book value over the next interval, such that:

$$
\log \left(1+\frac{D_{t+1}}{M_{t+1}}\right)=\log \left(1+\delta \frac{B_{t+1}}{M_{t+1}}\right)=\log \left(1+\delta \exp \left(b m_{t+1}\right)\right)
$$

Log-linearization around the unconditional mean of $b m, \overline{b m}$, and using Eq., (8), we have:

$$
\begin{aligned}
\log \left(1+\frac{D_{t+1}}{M_{t+1}}\right) \approx & \log (1+\delta \exp (\overline{b m}))+\frac{\delta \exp (\overline{b m})}{1+\delta \exp (\overline{b m})}\left(b m_{t+1}-\overline{b m}\right) \\
= & \log (1+\delta \exp (\overline{b m}))+ \\
& \frac{\delta \exp (\overline{b m})}{1+\delta \exp (\overline{b m})}\left[\frac{1}{1-\kappa}\left(\mu_{t+1}-\mu\right)-\frac{1}{1-\omega}\left(h_{t+1}-\mu\right)\right] .
\end{aligned}
$$

Taking conditional expectations and substiting for expected growth in market using (8) yields:

$$
\begin{aligned}
\mathbb{E}_{t}\left[\log \left(1+\frac{D_{t+1}}{M_{t+1}}\right)\right] & =K+\rho\left[\frac{\kappa}{1-\kappa}\left(\mu_{t}-\mu\right)-\frac{\omega}{1-\omega}\left(h_{t}-\mu\right)\right] \\
& =K+\rho\left[\kappa\left(b m_{t}-\overline{b m}\right)+\frac{\kappa-\omega}{1-\omega}\left(h_{t}-\mu\right)\right]
\end{aligned}
$$

where $K=\log (1+\delta \exp (\overline{b m}))$ and $\rho=\frac{\delta \exp (\overline{b m})}{1+\delta \exp (\overline{b m})}$.

Finally, under the proportional dividend assumption and clean-surplus accounting, growth in book and ROE can be related: $\log \left(R O E_{t+1}\right)=\log \left(\left(B_{t+1}+D_{t+1}\right) / B_{t}\right)=$ $\log (1+\delta)+\log \left(B_{t+1} / B_{t}\right)$ and $\mathbb{E}_{t}\left[\right.$ roe $\left._{t+1}\right]=\log (1+\delta)+h_{t}$. Combining this with (A.16) and (A.21) above obtains the desired linear expression as summarized in Eq., (10) in the 
body of the paper:

$$
\begin{aligned}
\mathbb{E}_{t}\left[r_{t+1}\right] & =\underbrace{\left[K+\frac{(\kappa-\omega)(1-\rho)}{1-\omega} \mu-(1-\kappa+\rho \kappa) b \bar{m}-A_{3} \log (1+\delta)\right]}_{A_{1}} \\
& +\underbrace{[1-\kappa+\rho \kappa]}_{A_{2}} b m_{t} \\
& +\underbrace{\left[\frac{\rho(\kappa-\omega)+1-\kappa]}{1-\omega}\right]}_{A_{3}} \mathbb{E}_{t}\left[\text { roe }_{t+1}\right] .
\end{aligned}
$$

\section{Dividend Payout and Expected Returns}

The relation between expected returns and dividend payout is derived by combining equations (A.16) and (A.21) and differentiating with respect to $\delta$ :

$$
\begin{aligned}
\frac{\partial E_{t}\left[r_{t+1}\right]}{\partial \delta} & =\frac{\partial \mu_{t}}{\partial \delta}+\frac{\partial E_{t}\left[\log \left(1+\frac{D_{t+1}}{M_{t+1}}\right)\right]}{\partial \delta} \\
& =0+\frac{\partial K}{\partial \delta}+\frac{\partial \rho}{\partial \delta}\left[\kappa\left(b m_{t}-b \bar{m}\right)+\frac{\kappa-\omega}{(1-\omega)}\left(h_{t}-\mu\right)\right]
\end{aligned}
$$

where

$$
\begin{aligned}
\frac{\partial K}{\partial \delta} & =\frac{\exp \left(b^{-}\right)}{1+\delta \exp (b \bar{m})}>0 \text { and } \\
\frac{\partial \rho}{\partial \delta} & =\frac{\exp (\bar{m})}{(1+\delta \exp (b m))^{2}}>0
\end{aligned}
$$

Thus, the coefficients on $b m_{t}$ and $h_{t}$ increase with dividend payout, so long as expected returns are more persistent than expected profitability: i.e., $\kappa>0$ and $\kappa>\omega$. 


\section{Expected Returns under Incomplete Information}

This subsection derives expected returns when investors do not directly observe book growth. To solve for stock returns in this setting, we must first solve the present-value problem; we do so by applying the law of iterated expectations to Eq., (6). (See the appendix of Pástor and Veronesi, 2009, for a simple and related example.) We deduce:

$$
b m_{t}=\overline{b m}+\frac{1}{1-\kappa}\left(\mu_{t}-\mu\right)-\frac{1}{1-\omega}\left(f_{t}-\mu\right) .
$$

Now, using the log-linearization in the previous subsection, we have:

$$
\begin{aligned}
\log \left(1+\frac{D_{t+1}}{M_{t+1}}\right) \approx & \log (1+\delta \exp (\overline{b m}))+\frac{\delta \exp (\overline{b m})}{1+\delta \exp (\overline{b m})}\left(b m_{t+1}-\overline{b m}\right) \\
= & \log (1+\delta \exp (\overline{b m}))+ \\
& \frac{\delta \exp (\overline{b m})}{1+\delta \exp (\overline{b m})}\left[\frac{1}{1-\kappa}\left(\mu_{t+1}-\mu\right)-\frac{1}{1-\omega}\left(f_{t+1}-\mu\right)\right] .
\end{aligned}
$$

Taking expectations conditional on $\mathcal{F}_{t}$, we have:

$$
\mathbb{E}\left[\log \left(1+\frac{D_{t+1}}{M_{t+1}}\right) \mid \mathcal{F}_{t}\right]=K+\rho\left(\frac{\kappa}{1-\kappa}\left(\mu_{t}-\mu\right)-\frac{\omega}{1-\omega}\left(f_{t}-\mu\right)\right),
$$

where $K$ and $\rho$ are given in the prior subsection. This implies that expected returns are given as follows:

$$
\mathbb{E}\left[r_{t+1} \mid \mathcal{F}_{t}\right]=A_{1}+A_{2} b m_{t}+A_{3}\left(f_{t}-y\right)
$$

Here $A_{1}=K-\rho \kappa \overline{b m}-(1-\kappa) \overline{b m}-A_{3} y+\frac{(\kappa-\omega)(1-\rho)}{(1-\omega)} \mu, A_{2}=\rho \kappa+(1-\kappa)$, and $A_{3}=$ $\frac{\rho(\kappa-\omega)+1-\kappa}{1-\omega} ; y=\log (1+\delta)$ 
From the updating rule (Eq., (21)), we can express this in term of current roe by noting that:

$$
f_{t}-\mu=\omega\left(f_{t-1}-\mu\right)+\frac{\omega v_{t-1}}{\sigma^{2}+\sigma_{r}^{2}+v_{t-1}}\left(\text { roe }_{t}-y-f_{t-1}\right) .
$$

Plugging this into the expected-returns Eq., (A.27), we have:

$$
\begin{aligned}
\mathbb{E}\left[r_{t+1} \mid \mathcal{F}_{t}\right]= & A_{1}+A_{2} b m_{t}+ \\
& A_{3}\left[\mu-y+\omega\left(f_{t-1}-\mu\right)+\frac{\omega v_{t-1}}{\sigma^{2}+\sigma_{r}^{2}+v_{t-1}}\left(\text { roe }_{t}-y-f_{t-1}\right)\right]
\end{aligned}
$$

Re-arranging, we obtain:

$$
\mathbb{E}\left[r_{t+1} \mid \mathcal{F}_{t}\right]=C_{1}(t)+C_{2}(t) f_{t-1}+C_{3} b m_{t}+C_{4}(t) \text { roe }_{t},
$$

where

$$
\begin{aligned}
C_{1}(t) & =A_{1}+A_{3}\left[\mu(1-\omega)-y\left(1+\frac{\omega v_{t-1}}{\sigma^{2}+\sigma_{r}^{2}+v_{t-1}}\right)\right] \\
C_{2}(t) & =A_{3}\left(\omega+\frac{\omega v_{t-1}}{\sigma^{2}+\sigma_{r}^{2}+v_{t-1}}\right) \\
C_{3} & =A_{2}, \\
C_{4}(t) & =A_{3} \frac{\omega v_{t-1}}{\sigma^{2}+\sigma_{r}^{2}+v_{t-1}} .
\end{aligned}
$$




\section{Table 1. Summary Statistics of Model Inputs}

Table 1 reports summary statistics by country for inputs to the regression of Eq., (13), bm $m_{t}$ and roe $_{t}$. The distributional summary statistics reported here are time-series averages of the corresponding cross-sectional statistics. $N$ represents the average number of observations per cross section in a particular country. Min Date and Max Date, respectively, denote the first and last calendar month for which data are available for the country in question, after imposing our sample selection requirements.

\begin{tabular}{|c|c|c|c|c|c|c|c|c|c|c|c|c|c|c|c|c|c|}
\hline \multirow[b]{2}{*}{ Country } & \multicolumn{7}{|c|}{$b m$} & \multicolumn{7}{|c|}{ roe } & \multirow[b]{2}{*}{$N$} & \multirow[b]{2}{*}{$\begin{array}{l}\text { Min } \\
\text { Date }\end{array}$} & \multirow[b]{2}{*}{$\begin{array}{l}\text { Max } \\
\text { Date }\end{array}$} \\
\hline & $q 5$ & $q 25$ & Med & $q 75$ & $q 95$ & Mean & $s d$ & $q 5$ & $q 25$ & Med & $q 75$ & $q 95$ & Mean & $s d$ & & & \\
\hline Australia & -2.11 & -1.13 & -0.61 & -0.18 & 0.28 & -0.72 & 0.78 & -0.17 & 0.06 & 0.12 & 0.20 & 0.43 & 0.13 & 0.25 & 287 & $1993 \mathrm{~m} 11$ & $2014 \mathrm{~m} 9$ \\
\hline Belgium & -1.57 & -0.68 & -0.22 & 0.11 & 0.64 & -0.32 & 0.70 & -0.24 & 0.03 & 0.09 & 0.15 & 0.36 & 0.08 & 0.24 & 106 & $2001 \mathrm{~m} 5$ & $2014 \mathrm{~m} 3$ \\
\hline Canada & -1.58 & -0.83 & -0.38 & 0.00 & 0.63 & -0.42 & 0.74 & -0.33 & 0.00 & 0.09 & 0.15 & 0.34 & 0.06 & 0.30 & 170 & $1985 \mathrm{~m} 5$ & $2010 \mathrm{~m} 9$ \\
\hline China & -2.25 & -1.56 & -1.17 & -0.82 & -0.37 & -1.23 & 0.61 & -0.09 & 0.03 & 0.08 & 0.15 & 0.30 & 0.09 & 0.21 & 1,188 & $2001 \mathrm{~m} 5$ & $2014 \mathrm{~m} 8$ \\
\hline Denmark & -1.76 & -0.65 & -0.15 & 0.24 & 0.78 & -0.27 & 0.83 & -0.39 & 0.00 & 0.08 & 0.15 & 0.34 & 0.05 & 0.29 & 134 & $1999 \mathrm{~m} 5$ & $2014 \mathrm{~m} 8$ \\
\hline Finland & -1.69 & -0.95 & -0.45 & -0.01 & 0.48 & -0.50 & 0.67 & -0.13 & 0.05 & 0.12 & 0.19 & 0.34 & 0.11 & 0.18 & 105 & $2001 \mathrm{~m} 5$ & $2014 \mathrm{~m} 9$ \\
\hline France & -1.76 & -0.94 & -0.45 & 0.01 & 0.71 & -0.46 & 0.84 & -0.25 & 0.04 & 0.10 & 0.16 & 0.31 & 0.08 & 0.25 & 441 & $1991 \mathrm{~m} 5$ & $2014 \mathrm{~m} 9$ \\
\hline Germany & -1.94 & -1.05 & -0.56 & -0.12 & 0.62 & -0.60 & 0.80 & -0.37 & 0.01 & 0.08 & 0.15 & 0.37 & 0.06 & 0.34 & 388 & $1991 \mathrm{~m} 5$ & $2014 \mathrm{~m} 9$ \\
\hline Greece & -1.77 & -0.85 & -0.31 & 0.14 & 0.75 & -0.38 & 0.79 & -0.11 & 0.02 & 0.08 & 0.15 & 0.36 & 0.09 & 0.18 & 141 & $2002 \mathrm{~m} 5$ & $2010 \mathrm{~m} 9$ \\
\hline Hong Kong & -1.68 & -0.67 & -0.05 & 0.52 & 1.25 & -0.12 & 0.91 & -0.11 & 0.05 & 0.11 & 0.18 & 0.37 & 0.11 & 0.23 & 250 & $1995 \mathrm{~m} 8$ & $2014 \mathrm{~m} 9$ \\
\hline India & -2.05 & -0.84 & -0.09 & 0.55 & 1.47 & -0.17 & 1.08 & -0.21 & 0.05 & 0.13 & 0.22 & 0.42 & 0.12 & 0.26 & 967 & $1997 \mathrm{~m} 8$ & $2014 \mathrm{~m} 9$ \\
\hline Indonesia & -1.78 & -0.81 & -0.19 & 0.37 & 1.10 & -0.26 & 0.95 & -0.34 & 0.00 & 0.11 & 0.21 & 0.47 & 0.10 & 0.41 & 210 & $1999 \mathrm{~m} 5$ & $2014 \mathrm{~m} 9$ \\
\hline Israel & -1.67 & -0.51 & -0.07 & 0.25 & 0.67 & -0.21 & 0.75 & -0.33 & 0.02 & 0.10 & 0.18 & 0.47 & 0.09 & 0.30 & 183 & $2008 \mathrm{~m} 5$ & $2014 \mathrm{~m} 8$ \\
\hline Italy & -1.72 & -0.90 & -0.43 & 0.02 & 0.73 & -0.44 & 0.84 & -0.21 & 0.02 & 0.08 & 0.14 & 0.29 & 0.07 & 0.24 & 181 & $1998 \mathrm{~m} 5$ & $2014 \mathrm{~m} 9$ \\
\hline Japan & -1.55 & -0.71 & -0.27 & 0.10 & 0.57 & -0.35 & 0.67 & -0.13 & 0.02 & 0.05 & 0.09 & 0.20 & 0.04 & 0.18 & 2,530 & $1989 \mathrm{~m} 2$ & $2014 \mathrm{~m} 9$ \\
\hline Malaysia & -1.64 & -0.79 & -0.34 & 0.06 & 0.55 & -0.41 & 0.70 & -0.10 & 0.05 & 0.10 & 0.16 & 0.30 & 0.10 & 0.19 & 322 & $1993 \mathrm{~m} 3$ & $2014 \mathrm{~m} 9$ \\
\hline Netherlands & -2.09 & -1.17 & -0.62 & -0.16 & 0.42 & -0.70 & 0.81 & -0.25 & 0.04 & 0.13 & 0.22 & 0.47 & 0.12 & 0.30 & 131 & $1997 \mathrm{~m} 5$ & $2011 \mathrm{~m} 8$ \\
\hline Norway & -1.81 & -0.91 & -0.36 & 0.19 & 1.38 & -0.33 & 0.96 & -0.60 & -0.03 & 0.09 & 0.17 & 0.42 & 0.03 & 0.37 & 118 & $2001 \mathrm{~m} 5$ & $2014 \mathrm{~m} 9$ \\
\hline Pakistan & -1.59 & -0.71 & -0.16 & 0.41 & 1.23 & -0.16 & 0.91 & -0.21 & 0.06 & 0.17 & 0.28 & 0.52 & 0.16 & 0.29 & 195 & $2004 \mathrm{~m} 12$ & $2014 \mathrm{~m} 9$ \\
\hline Philippines & -2.51 & -1.08 & -0.49 & 0.07 & 0.82 & -0.63 & 1.18 & -0.12 & 0.04 & 0.11 & 0.18 & 0.41 & 0.12 & 0.32 & 138 & $2007 \mathrm{~m} 5$ & $2014 \mathrm{~m} 9$ \\
\hline South Africa & -1.99 & -1.06 & -0.53 & -0.08 & 0.76 & -0.57 & 0.87 & -0.05 & 0.11 & 0.19 & 0.27 & 0.54 & 0.21 & 0.26 & 186 & $1997 \mathrm{~m} 11$ & $2014 \mathrm{~m} 9$ \\
\hline South Korea & -1.24 & -0.40 & 0.11 & 0.59 & 1.20 & 0.06 & 0.76 & -0.40 & 0.00 & 0.06 & 0.13 & 0.28 & 0.03 & 0.31 & 893 & $1994 \mathrm{~m} 5$ & $2014 \mathrm{~m} 9$ \\
\hline Spain & -2.07 & -1.08 & -0.62 & -0.27 & 0.35 & -0.70 & 0.77 & -0.14 & 0.06 & 0.12 & 0.18 & 0.38 & 0.12 & 0.21 & 114 & $1998 \mathrm{~m} 5$ & $2014 \mathrm{~m} 4$ \\
\hline Sweden & -2.10 & -1.20 & -0.62 & -0.10 & 0.56 & -0.67 & 0.83 & -0.70 & -0.02 & 0.11 & 0.20 & 0.41 & 0.02 & 0.48 & 246 & $1998 \mathrm{~m} 5$ & $2014 \mathrm{~m} 9$ \\
\hline Switzerland & -1.78 & -0.91 & -0.36 & 0.08 & 0.94 & -0.39 & 0.88 & -0.20 & 0.04 & 0.10 & 0.16 & 0.31 & 0.08 & 0.22 & 171 & $1998 \mathrm{~m} 5$ & $2014 \mathrm{~m} 9$ \\
\hline Taiwan & -1.41 & -0.72 & -0.29 & 0.09 & 0.50 & -0.35 & 0.59 & -0.16 & 0.02 & 0.08 & 0.15 & 0.29 & 0.07 & 0.18 & 488 & $1999 \mathrm{~m} 5$ & $2014 \mathrm{~m} 9$ \\
\hline Thailand & -1.50 & -0.65 & -0.14 & 0.32 & 0.91 & -0.20 & 0.77 & -0.27 & 0.03 & 0.11 & 0.19 & 0.38 & 0.10 & 0.27 & 289 & $1993 \mathrm{~m} 5$ & $2014 \mathrm{~m} 9$ \\
\hline UK & -2.16 & -1.16 & -0.52 & 0.02 & 0.43 & -0.63 & 0.88 & -0.10 & 0.04 & 0.13 & 0.22 & 0.46 & 0.14 & 0.27 & 656 & $1990 \mathrm{~m} 6$ & $2014 \mathrm{~m} 9$ \\
\hline US & -2.04 & -1.12 & -0.60 & -0.20 & 0.37 & -0.70 & 0.77 & -0.34 & 0.03 & 0.11 & 0.17 & 0.38 & 0.08 & 0.36 & 3,249 & $1984 \mathrm{~m} 5$ & $2014 \mathrm{~m} 9$ \\
\hline
\end{tabular}




\section{Table 2. Summary Statistics of Estimated Coefficients}

Table 2 reports the coefficients on $b m_{t}$ and $r o e_{t}$. The coefficients are estimated by Fama and MacBeth (1973) cross-sectional regressions, in which monthly log-returns are regressed on firm characteristics for each calendar month. We assume accounting data is known four months after the fiscal-year end date. Publicly available financial data on book values and ROE are matched to one-month-ahead returns for twelve months, starting four months after the fiscal-year end date as in Lewellen (2015). The estimation uses the cross-section of firms in a given country for a particular calendar month. Columns (1)-(3) report the Fama-MacBeth coefficients and standard errors (in square brackets below coefficients). Column (4) reports the average number of firms per cross section, column (5) reports the total number of months included in the Fama-Macbeth estimates, and column (6) reports the average of the cross-sectionalregression adjusted $R^{2}$ values. Levels of significance are indicated by $*{ }^{* *}$, and ${ }^{* * *}$, representing 10 percent, 5 percent, and 1 percent, respectively.

\begin{tabular}{|c|c|c|c|c|c|c|}
\hline & (1) & $(2)$ & $(3)$ & (4) & (5) & (6) \\
\hline Country & $b m$ & roe & cons & $\mathbf{N}$ & $\begin{array}{l}\text { No. of } \\
\text { Periods }\end{array}$ & $\operatorname{Adj} \mathbf{R}^{2}$ \\
\hline Australia & $\begin{array}{c}0.0033^{* * *} \\
{[0.001]}\end{array}$ & $\begin{array}{c}0.0103^{* * *} \\
{[0.004]}\end{array}$ & $\begin{array}{c}0.0048^{*} \\
{[0.002]}\end{array}$ & 286 & 252 & 0.019 \\
\hline Belgium & $\begin{array}{c}0.0047^{* * *} \\
{[0.001]}\end{array}$ & $\begin{array}{c}0.0242^{* * *} \\
{[0.006]}\end{array}$ & $\begin{array}{l}0.0015 \\
{[0.004]}\end{array}$ & 106 & 139 & 0.020 \\
\hline Canada & $\begin{array}{c}-0.0004 \\
{[0.001]}\end{array}$ & $\begin{array}{c}0.0095^{* *} \\
{[0.004]}\end{array}$ & $\begin{array}{c}-0.0004 \\
{[0.003]}\end{array}$ & 170 & 300 & 0.016 \\
\hline China & $\begin{array}{c}0.0051^{* * *} \\
{[0.001]}\end{array}$ & $\begin{array}{l}0.0031 \\
{[0.005]}\end{array}$ & $\begin{array}{l}0.0086 \\
{[0.008]}\end{array}$ & 1,182 & 161 & 0.022 \\
\hline Denmark & $\begin{array}{l}0.0000 \\
{[0.002]}\end{array}$ & $\begin{array}{c}0.0136^{* * *} \\
{[0.004]}\end{array}$ & $\begin{array}{l}0.0003 \\
{[0.004]}\end{array}$ & 134 & 185 & 0.028 \\
\hline Finland & $\begin{array}{c}0.0091^{* * *} \\
{[0.002]}\end{array}$ & $\begin{array}{c}0.0318^{* * *} \\
{[0.009]}\end{array}$ & $\begin{array}{c}-0.0014 \\
{[0.005]}\end{array}$ & 106 & 108 & 0.039 \\
\hline France & $\begin{array}{c}0.0030^{* * *} \\
{[0.001]}\end{array}$ & $\begin{array}{c}0.0155^{* * *} \\
{[0.003]}\end{array}$ & $\begin{array}{l}0.0021 \\
{[0.003]}\end{array}$ & 440 & 282 & 0.019 \\
\hline Germany & $\begin{array}{c}0.0025^{* * *} \\
{[0.001]}\end{array}$ & $\begin{array}{c}0.0103^{* * *} \\
{[0.002]}\end{array}$ & $\begin{array}{l}-0.0016 \\
{[0.003]}\end{array}$ & 387 & 282 & 0.015 \\
\hline Greece & $\begin{array}{l}0.0006 \\
{[0.002]}\end{array}$ & $\begin{array}{c}0.0287^{* * *} \\
{[0.008]}\end{array}$ & $\begin{array}{c}-0.0133 \\
{[0.009]}\end{array}$ & 141 & 100 & 0.021 \\
\hline HongKong & $\begin{array}{c}0.0067^{* * *} \\
{[0.001]}\end{array}$ & $\begin{array}{c}0.0223^{* * *} \\
{[0.007]}\end{array}$ & $\begin{array}{c}-0.0015 \\
{[0.005]}\end{array}$ & 250 & 229 & 0.020 \\
\hline India & $\begin{array}{l}0.0016 \\
{[0.002]}\end{array}$ & $\begin{array}{c}0.0129^{* *} \\
{[0.005]}\end{array}$ & $\begin{array}{l}0.0026 \\
{[0.007]}\end{array}$ & 963 & 207 & 0.029 \\
\hline Indonesia & $\begin{array}{c}0.0060^{* * *} \\
{[0.002]}\end{array}$ & $\begin{array}{c}0.0136^{* * *} \\
{[0.003]}\end{array}$ & $\begin{array}{l}0.0090 \\
{[0.006]}\end{array}$ & 210 & 186 & 0.015 \\
\hline Israel & $\begin{array}{l}0.0007 \\
{[0.002]}\end{array}$ & $\begin{array}{c}0.0234^{* * *} \\
{[0.006]}\end{array}$ & $\begin{array}{l}-0.0008 \\
{[0.009]}\end{array}$ & 182 & 77 & 0.017 \\
\hline Italy & $\begin{array}{c}0.0021^{* *} \\
{[0.001]}\end{array}$ & $\begin{array}{c}0.0182^{* * *} \\
{[0.004]}\end{array}$ & $\begin{array}{r}-0.0019 \\
{[0.004]}\end{array}$ & 181 & 198 & 0.025 \\
\hline
\end{tabular}


Table 2. Continued

\begin{tabular}{|c|c|c|c|c|c|c|}
\hline & $(1)$ & $(2)$ & $(3)$ & $(4)$ & (5) & $(6)$ \\
\hline Country & $b m$ & roe & cons & $\mathbf{N}$ & $\begin{array}{l}\text { No. of } \\
\text { Periods }\end{array}$ & Adj $\mathbf{R}^{2}$ \\
\hline Japan & $\begin{array}{c}0.0067^{* * *} \\
{[0.001]}\end{array}$ & $\begin{array}{c}0.0069^{* * *} \\
{[0.002]}\end{array}$ & $\begin{array}{r}-0.0007 \\
{[0.004]}\end{array}$ & 2,522 & 309 & 0.017 \\
\hline Malaysia & $\begin{array}{c}0.0064^{* * *} \\
{[0.001]}\end{array}$ & $\begin{array}{c}0.0238^{* * *} \\
{[0.005]}\end{array}$ & $\begin{array}{l}0.0009 \\
{[0.006]}\end{array}$ & 321 & 260 & 0.017 \\
\hline Netherlands & $\begin{array}{c}0.0034^{*} \\
{[0.002]}\end{array}$ & $\begin{array}{c}0.0113^{* *} \\
{[0.006]}\end{array}$ & $\begin{array}{l}0.0002 \\
{[0.004]}\end{array}$ & 131 & 172 & 0.030 \\
\hline Norway & $\begin{array}{l}0.0013 \\
{[0.001]}\end{array}$ & $\begin{array}{c}0.0211^{* * *} \\
{[0.006]}\end{array}$ & $\begin{array}{l}0.0014 \\
{[0.004]}\end{array}$ & 118 & 152 & 0.024 \\
\hline Pakistan & $\begin{array}{c}-0.0004 \\
{[0.002]}\end{array}$ & $\begin{array}{c}0.0105^{* *} \\
{[0.005]}\end{array}$ & $\begin{array}{c}0.0120^{*} \\
{[0.006]}\end{array}$ & 195 & 116 & 0.022 \\
\hline Philippines & $\begin{array}{c}0.0036^{* *} \\
{[0.002]}\end{array}$ & $\begin{array}{c}0.0100^{*} \\
{[0.006]}\end{array}$ & $\begin{array}{l}0.0095 \\
{[0.006]}\end{array}$ & 138 & 79 & 0.010 \\
\hline South Africa & $\begin{array}{c}0.0027^{* *} \\
{[0.001]}\end{array}$ & $\begin{array}{l}0.0010 \\
{[0.004]}\end{array}$ & $\begin{array}{c}0.0098^{* * *} \\
{[0.003]}\end{array}$ & 185 & 204 & 0.015 \\
\hline South Korea & $\begin{array}{c}0.0097^{* * *} \\
{[0.002]}\end{array}$ & $\begin{array}{c}0.0159^{* * *} \\
{[0.004]}\end{array}$ & $\begin{array}{c}-0.0054 \\
{[0.006]}\end{array}$ & 889 & 246 & 0.022 \\
\hline Spain & $\begin{array}{c}0.0029^{* *} \\
{[0.001]}\end{array}$ & $\begin{array}{c}0.0256^{* * *} \\
{[0.007]}\end{array}$ & $\begin{array}{l}0.0001 \\
{[0.004]}\end{array}$ & 115 & 184 & 0.031 \\
\hline Sweden & $\begin{array}{l}0.0012 \\
{[0.001]}\end{array}$ & $\begin{array}{c}0.0120 * * * \\
{[0.003]}\end{array}$ & $\begin{array}{l}0.0001 \\
{[0.004]}\end{array}$ & 246 & 198 & 0.029 \\
\hline Switzerland & $\begin{array}{c}0.0022^{* *} \\
{[0.001]}\end{array}$ & $\begin{array}{c}0.0080^{*} \\
{[0.005]}\end{array}$ & $\begin{array}{l}0.0027 \\
{[0.003]}\end{array}$ & 170 & 198 & 0.024 \\
\hline Taiwan & $\begin{array}{c}0.0063^{* *} \\
{[0.003]}\end{array}$ & $\begin{array}{c}0.0314^{* * *} \\
{[0.007]}\end{array}$ & $\begin{array}{l}-0.0015 \\
{[0.007]}\end{array}$ & 486 & 186 & 0.048 \\
\hline Thailand & $\begin{array}{c}0.0074^{* * *} \\
{[0.001]}\end{array}$ & $\begin{array}{c}0.0208^{* * *} \\
{[0.006]}\end{array}$ & $\begin{array}{l}0.0002 \\
{[0.005]}\end{array}$ & 289 & 258 & 0.019 \\
\hline UK & $\begin{array}{c}0.0022^{* * *} \\
{[0.001]}\end{array}$ & $\begin{array}{c}0.0083^{* * *} \\
{[0.002]}\end{array}$ & $\begin{array}{c}0.0045^{*} \\
{[0.003]}\end{array}$ & 654 & 293 & 0.011 \\
\hline US & $\begin{array}{c}0.0030^{* * *} \\
{[0.001]}\end{array}$ & $\begin{array}{c}0.0047^{* * *} \\
{[0.001]}\end{array}$ & $\begin{array}{c}0.0065^{* *} \\
{[0.003]}\end{array}$ & 3,244 & 366 & 0.011 \\
\hline
\end{tabular}




\section{Table 3. Summary Statistics of Expected Return Proxies}

Table 3 columns (1)-(3) and (5)-(9) report summary statistics by country for the monthly ERPs calculated using Eq., (13). The table reports time-series averages of the corresponding cross-sectional statistics. Expected-return proxies for a particular calendar month are calculated using firm fundamentals and the cumulative rolling average of the estimated cross-sectional coefficients as of the end of the previous calendar month. For calculating cumulative averages, we use a burn-in period of forty months. Column(4) reports the time-series average of the cross-sectional mean of a proxy for expected simple returns, computed as $\hat{\mathbb{E}}_{t}\left[R_{i, t+1}\right]=\exp \left(\hat{\mu}_{i, t}+0.5 \times \hat{\sigma}_{i, t+1}^{2}\right)$, where $\hat{\mu}_{i, t}$ is our expected log return estimate, and $\hat{\sigma}_{i, t+1}^{2}$ is an estimate of the expected volatility in log returns based on the average squared daily returns from the prior month scaled by $252 / 12$. Finally, the last three columns report the time-series averages of the cross-sectional mean realized log monthly returns, variance of realized log monthly returns, and mean realized simple monthly returns.

\begin{tabular}{|c|c|c|c|c|c|c|c|c|c|c|c|c|}
\hline & $(1)$ & $(2)$ & (3) & $(4)$ & (5) & $(6)$ & $(7)$ & $(8)$ & (9) & $(10)$ & $(11)$ & $(12)$ \\
\hline & $q 5$ & $q 25$ & Mean & $\begin{array}{c}\text { Mean } \\
\text { (Simple) }\end{array}$ & Median & q75 & $q 95$ & $s d$ & $N$ & $\begin{array}{c}\text { Mean } \\
\text { Log Returns }\end{array}$ & $\begin{array}{c}\text { Variance } \\
\text { Log Returns }\end{array}$ & $\begin{array}{c}\text { Mean } \\
\text { Simple Returns }\end{array}$ \\
\hline Australia & -0.0034 & 0.0029 & 0.0050 & 0.0106 & 0.0069 & 0.0095 & 0.0043 & 0.0053 & 268 & 0.0040 & 0.0116 & 0.0095 \\
\hline Belgium & -0.0061 & 0.0013 & 0.0037 & 0.0086 & 0.0055 & 0.0098 & 0.0030 & 0.0057 & 76 & 0.0021 & 0.0119 & 0.0071 \\
\hline Canada & -0.0043 & 0.0007 & 0.0020 & 0.0156 & 0.0032 & 0.0062 & 0.0016 & 0.0047 & 153 & -0.0002 & 0.0280 & 0.0115 \\
\hline China & -0.0105 & -0.0054 & -0.0027 & 0.0074 & -0.0004 & 0.0028 & -0.0032 & 0.0048 & 1,118 & 0.0028 & 0.0184 & 0.0123 \\
\hline Denmark & -0.0023 & 0.0027 & 0.0040 & 0.0129 & 0.0049 & 0.0069 & 0.0035 & 0.0033 & 110 & -0.0003 & 0.0183 & 0.0074 \\
\hline Finland & -0.0120 & -0.0043 & 0.0006 & 0.0066 & 0.0051 & 0.0117 & 0.0003 & 0.0078 & 68 & 0.0024 & 0.0141 & 0.0078 \\
\hline France & -0.0031 & 0.0023 & 0.0036 & 0.0110 & 0.0047 & 0.0074 & 0.0030 & 0.0047 & 421 & 0.0018 & 0.0144 & 0.0084 \\
\hline Germany & -0.0072 & -0.0033 & -0.0020 & 0.0072 & -0.0008 & 0.0017 & -0.0023 & 0.0035 & 366 & -0.0029 & 0.0170 & 0.0041 \\
\hline Greece & -0.0126 & -0.0064 & -0.0042 & 0.0058 & -0.0019 & 0.0055 & -0.0041 & 0.0072 & 93 & -0.0104 & 0.0170 & -0.0012 \\
\hline HongKong & -0.0167 & -0.0079 & -0.0047 & 0.0043 & -0.0017 & 0.0038 & -0.0055 & 0.0088 & 229 & 0.0010 & 0.0199 & 0.0125 \\
\hline India & -0.0043 & 0.0002 & 0.0014 & 0.0148 & 0.0026 & 0.0053 & 0.0011 & 0.0041 & 928 & 0.0048 & 0.0292 & 0.0207 \\
\hline Indonesia & -0.0038 & 0.0026 & 0.0064 & 0.0277 & 0.0102 & 0.0149 & 0.0061 & 0.0070 & 182 & 0.0082 & 0.0466 & 0.0263 \\
\hline Israel & -0.0108 & -0.0043 & -0.0028 & 0.0003 & -0.0016 & 0.0036 & -0.0031 & 0.0063 & 108 & 0.0013 & 0.0132 & 0.0105 \\
\hline Italy & -0.0077 & -0.0034 & -0.0019 & 0.0028 & -0.0006 & 0.0017 & -0.0023 & 0.0041 & 150 & -0.0025 & 0.0107 & 0.0033 \\
\hline Japan & -0.0110 & -0.0051 & -0.0020 & 0.0064 & 0.0006 & 0.0040 & -0.0026 & 0.0049 & 2,371 & -0.0035 & 0.0176 & 0.0041 \\
\hline Malaysia & -0.0075 & -0.0018 & 0.0010 & 0.0073 & 0.0033 & 0.0064 & 0.0004 & 0.0050 & 301 & 0.0008 & 0.0310 & 0.0122 \\
\hline Netherlands & -0.0081 & -0.0026 & 0.0000 & 0.0101 & 0.0021 & 0.0048 & -0.0007 & 0.0051 & 98 & -0.0014 & 0.0190 & 0.0101 \\
\hline Norway & -0.0080 & 0.0027 & 0.0051 & 0.0074 & 0.0071 & 0.0111 & 0.0040 & 0.0068 & 88 & 0.0014 & 0.0152 & 0.0056 \\
\hline Pakistan & 0.0047 & 0.0076 & 0.0092 & 0.0148 & 0.0106 & 0.0132 & 0.0091 & 0.0030 & 148 & 0.0137 & 0.0253 & 0.0102 \\
\hline Philippines & -0.0013 & 0.0071 & 0.0090 & 0.0199 & 0.0107 & 0.0132 & 0.0081 & 0.0057 & 78 & 0.0044 & 0.0197 & 0.0237 \\
\hline South Africa & -0.0023 & 0.0034 & 0.0063 & 0.0196 & 0.0086 & 0.0132 & 0.0060 & 0.0050 & 158 & 0.0092 & 0.0251 & 0.0150 \\
\hline South Korea & -0.0227 & -0.0135 & -0.0087 & 0.0129 & -0.0045 & 0.0007 & -0.0096 & 0.0078 & 855 & -0.0041 & 0.0159 & 0.0162 \\
\hline Spain & -0.0071 & 0.0004 & 0.0025 & 0.0067 & 0.0042 & 0.0075 & 0.0018 & 0.0066 & 90 & 0.0008 & 0.0099 & 0.0059 \\
\hline Sweden & -0.0132 & -0.0029 & -0.0007 & 0.0091 & 0.0010 & 0.0039 & -0.0019 & 0.0067 & 212 & -0.0012 & 0.0222 & 0.0079 \\
\hline Switzerland & -0.0028 & -0.0003 & 0.0012 & 0.0068 & 0.0023 & 0.0046 & 0.0010 & 0.0027 & 145 & 0.0020 & 0.0117 & 0.0067 \\
\hline Taiwan & -0.0147 & -0.0072 & -0.0049 & 0.0006 & -0.0032 & -0.0001 & -0.0059 & 0.0064 & 449 & -0.0002 & 0.0150 & 0.0088 \\
\hline Thailand & -0.0263 & -0.0106 & -0.0058 & 0.0114 & -0.0023 & 0.0030 & -0.0076 & 0.0111 & 272 & 0.0021 & 0.0331 & 0.0150 \\
\hline UK & 0.0023 & 0.0043 & 0.0053 & 0.0095 & 0.0063 & 0.0082 & 0.0053 & 0.0026 & 599 & 0.0042 & 0.0083 & 0.0096 \\
\hline US & 0.0014 & 0.0045 & 0.0059 & 0.0173 & 0.0069 & 0.0084 & 0.0055 & 0.0027 & 3,004 & 0.0051 & 0.0219 & 0.0145 \\
\hline
\end{tabular}


Table 4. Return Regressions

Table 4 reports the results of Fama-MacBeth regressions of one-month-ahead log returns on the ERPs for each country. Expected returns are winsorized at the top and bottom one-percent. Standard errors are reported in brackets below the coefficient estimates. The last row reports the $p$-value for the F-test of the null hypothesis that the slope coefficient is equal to 1 . Levels of significance are indicated by $*$, **, and $* * *$, representing 10 percent, 5 percent, and 1 percent, respectively.

\begin{tabular}{|c|c|c|c|c|c|c|c|c|c|c|}
\hline & Australia & Belgium & Canada & China & Denmark & Finland & France & Germany & Greece & Hong Kong \\
\hline \multirow[t]{2}{*}{$\hat{\mathbb{E}}\left[r_{i, t+1}\right]$} & $0.5577^{* *}$ & $1.0484^{* * *}$ & $0.7340^{* *}$ & $0.4085^{* *}$ & $1.5072^{* * *}$ & $0.4111^{*}$ & $1.3956^{* * *}$ & $1.7270^{* * *}$ & 0.2810 & $0.8958^{* * *}$ \\
\hline & [0.238] & [0.319] & {$[0.335]$} & [0.204] & [0.530] & {$[0.221]$} & [0.347] & [0.333] & {$[0.303]$} & [0.170] \\
\hline \multirow[t]{2}{*}{ Cons } & 0.0007 & -0.0017 & -0.0028 & 0.0121 & -0.0004 & -0.0013 & -0.0042 & -0.0002 & -0.0116 & $0.0102^{*}$ \\
\hline & {$[0.003]$} & {$[0.005]$} & {$[0.003]$} & {$[0.009]$} & {$[0.005]$} & {$[0.007]$} & {$[0.003]$} & {$[0.003]$} & {$[0.011]$} & {$[0.005]$} \\
\hline $\mathrm{N}$ & 67,239 & 9,991 & 45,514 & 178,906 & 20,186 & 6,779 & 118,351 & 102,838 & 9,236 & 52,309 \\
\hline$R^{2}$ & 0.016 & 0.025 & 0.016 & 0.008 & 0.025 & 0.014 & 0.012 & 0.009 & 0.012 & 0.016 \\
\hline \multirow[t]{2}{*}{$p$-Value } & 0.064 & 0.880 & 0.428 & 0.004 & 0.340 & 0.010 & 0.255 & 0.030 & 0.021 & 0.541 \\
\hline & India & Indonesia & Israel & Italy & Japan & Malaysia & Netherlands & Norway & Pakistan & Philippines \\
\hline \multirow{2}{*}{$\hat{\mathbb{E}}\left[r_{i, t+1}\right]$} & $0.7374^{* *}$ & $1.0454^{* * *}$ & $1.6767^{* * *}$ & $1.3071^{* * *}$ & $0.9429^{* * *}$ & $1.4109^{* * *}$ & $0.8810^{* *}$ & $1.1139^{* *}$ & 1.0769 & $1.1622^{* *}$ \\
\hline & {$[0.299]$} & {$[0.227]$} & {$[0.414]$} & {$[0.255]$} & {$[0.155]$} & {$[0.206]$} & {$[0.406]$} & {$[0.440]$} & {$[0.879]$} & {$[0.487]$} \\
\hline \multirow[t]{2}{*}{ Cons } & 0.0029 & 0.0056 & $0.0158^{* *}$ & 0.0010 & -0.0001 & -0.0004 & -0.0043 & -0.0029 & 0.0004 & -0.0033 \\
\hline & {$[0.008]$} & {$[0.005]$} & {$[0.007]$} & {$[0.004]$} & {$[0.003]$} & {$[0.006]$} & {$[0.005]$} & {$[0.005]$} & {$[0.012]$} & {$[0.008]$} \\
\hline $\mathrm{N}$ & 191,194 & 33,691 & 8,183 & 29,548 & 730,374 & 78,049 & 16,696 & 13,307 & 16,883 & 6,050 \\
\hline$R^{2}$ & 0.008 & 0.013 & 0.015 & 0.02 & 0.013 & 0.012 & 0.024 & 0.025 & 0.019 & 0.012 \\
\hline \multirow[t]{2}{*}{$p$-Value } & 0.380 & 0.842 & 0.111 & 0.231 & 0.713 & 0.047 & 0.770 & 0.796 & 0.931 & 0.741 \\
\hline & South Africa & South Korea & Spain & Sweden & Switzerland & Taiwan & Thailand & 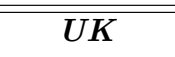 & $\overline{U S}$ & \\
\hline \multirow[t]{2}{*}{$\hat{\mathbb{E}}\left[r_{i, t+1}\right]$} & -0.0378 & $1.5412^{* * *}$ & $1.0350 * * *$ & $1.0922^{* * *}$ & $0.7494^{*}$ & $0.9327^{* * *}$ & $0.6660 * * *$ & $1.1200^{* * *}$ & $1.2794^{* * *}$ & \\
\hline & [0.170] & {$[0.245]$} & [0.249] & {$[0.253]$} & {$[0.409]$} & [0.167] & [0.141] & {$[0.255]$} & {$[0.350]$} & \\
\hline \multirow[t]{2}{*}{ Cons } & $0.0146^{* * *}$ & 0.0105 & -0.0000 & 0.0030 & 0.0016 & $0.0097^{*}$ & $0.0082^{*}$ & -0.0022 & -0.0039 & \\
\hline & [0.003] & {$[0.007]$} & {$[0.004]$} & {$[0.004]$} & {$[0.004]$} & {$[0.006]$} & {$[0.005]$} & {$[0.003]$} & {$[0.004]$} & \\
\hline $\mathrm{N}$ & 32,104 & 209,537 & 16,290 & 41,673 & 28,656 & 82,991 & 69,932 & 174,792 & $1,096,559$ & \\
\hline$R^{2}$ & 0.012 & 0.017 & 0.027 & 0.022 & 0.018 & 0.013 & 0.015 & 0.007 & 0.008 & \\
\hline$p$-Val & 0.000 & 0.028 & 0.888 & 0.716 & 0.540 & 0.687 & 0.019 & 0.638 & 0.425 & \\
\hline
\end{tabular}


Table 5. Stock Returns of Portfolios Sorted on Expected Return Estimates

Table 5 reports the country-specific average one-month-ahead log returns for each quintile portfolio of the ERP. Quintile portfolios are constructed for each calendar month between and including Min Date and Max Date in Table 1. Column (6) [(7)] reports the average spread in mean [median] $\log$ returns between the fifth and first quintile portfolios. Column (8) reports the average spread in mean net returns between the fifth and first quintile portfolios. OLS standard errors are used in significance tests, using the time-series of mean or median quintile spreads. Levels of significance are indicated by ${ }^{*},{ }^{*}$, and ${ }^{* * *}$, representing 10 percent, 5 percent, and 1 percent, respectively.

\begin{tabular}{|c|c|c|c|c|c|c|c|}
\hline & (1) & (2) & (3) & (4) & (5) & (6) & (7) \\
\hline Country & $Q 1$ & $Q^{2}$ & Q3 & Q4 & Q5 & $\begin{array}{c}\text { Spread } \\
\text { Mean } \\
Q 5-Q 1\end{array}$ & $\begin{array}{c}\text { Spread } \\
\text { Median } \\
Q 5-Q 1\end{array}$ \\
\hline Australia & -0.0008 & 0.0045 & 0.0036 & 0.0044 & 0.0046 & $0.0054^{* *}$ & $0.0040^{* *}$ \\
\hline Belgium & -0.0048 & 0.0031 & 0.0005 & 0.0057 & 0.0067 & $0.0115^{* * *}$ & 0.0034 \\
\hline Canada & -0.0087 & -0.0002 & 0.0026 & 0.0018 & -0.0010 & $0.0077^{* *}$ & 0.0035 \\
\hline China & 0.0060 & 0.0095 & 0.0121 & 0.0116 & 0.0113 & $0.0053^{* *}$ & 0.0037 \\
\hline Denmark & -0.0083 & -0.0013 & 0.0037 & 0.0044 & 0.0041 & $0.0124^{* * *}$ & $0.0117^{* * *}$ \\
\hline Finland & -0.0008 & -0.0010 & 0.0010 & 0.0057 & 0.0045 & 0.0053 & 0.0030 \\
\hline France & -0.0075 & 0.0006 & 0.0024 & 0.0043 & 0.0052 & $0.0127^{* * *}$ & $0.0088^{* * *}$ \\
\hline Germany & -0.0124 & -0.0043 & 0.0000 & 0.0010 & -0.0018 & $0.0106^{* * *}$ & $0.0085^{* * *}$ \\
\hline Greece & -0.0205 & -0.0118 & -0.0107 & -0.0085 & -0.0135 & 0.0070 & 0.0075 \\
\hline HongKong & -0.0076 & 0.0051 & 0.0072 & 0.0089 & 0.0097 & $0.0173^{* * *}$ & $0.0142^{* * *}$ \\
\hline India & 0.0026 & 0.0098 & 0.0109 & 0.0124 & 0.0053 & 0.0027 & 0.0029 \\
\hline Indonesia & 0.0046 & 0.0080 & 0.0119 & 0.0145 & 0.021 & $0.0164^{* * *}$ & 0.0049 \\
\hline Israel & -0.0043 & 0.0099 & 0.0116 & 0.0116 & 0.0159 & $0.0203^{* * *}$ & $0.0125^{* * *}$ \\
\hline Italy & -0.011 & -0.0009 & -0.0014 & 0.0001 & 0.0008 & $0.0118^{* * *}$ & $0.0122^{* * *}$ \\
\hline Japan & -0.0099 & -0.0030 & -0.0013 & 0.0006 & 0.0013 & $0.0112^{* * *}$ & $0.0100^{* * *}$ \\
\hline Malaysia & -0.0122 & -0.0037 & -0.0009 & 0.0020 & 0.0034 & $0.0156^{* * *}$ & $0.0105^{* * *}$ \\
\hline Netherlands & -0.0084 & -0.0047 & -0.0019 & -0.0006 & 0.0011 & $0.0095^{* *}$ & $0.0089^{* * *}$ \\
\hline Norway & -0.0122 & -0.0001 & 0.0033 & 0.0056 & 0.0027 & $0.0149 * * *$ & $0.0194^{* * *}$ \\
\hline Pakistan & 0.0073 & 0.0132 & 0.0125 & 0.0124 & 0.0118 & 0.0045 & $0.0135^{* *}$ \\
\hline Philippines & 0.0003 & 0.0047 & 0.0085 & 0.0095 & 0.0149 & $0.0147^{* *}$ & $0.0090^{* *}$ \\
\hline South Africa & 0.0116 & 0.0113 & 0.0124 & 0.0121 & 0.0134 & 0.0018 & -0.0009 \\
\hline South Korea & -0.0224 & -0.0074 & -0.0040 & 0.0035 & 0.0069 & $0.0294^{* * *}$ & $0.0238^{* * *}$ \\
\hline Spain & -0.0064 & 0.0000 & 0.0029 & 0.0075 & 0.0056 & $0.0120^{* * *}$ & $0.0107^{* * *}$ \\
\hline Sweden & -0.0125 & 0.0018 & 0.0047 & 0.0052 & 0.0053 & $0.0178^{* * *}$ & $0.0180^{* * *}$ \\
\hline Switzerland & 0.0004 & 0.0037 & 0.0015 & 0.0039 & 0.0054 & $0.0050^{*}$ & 0.0042 \\
\hline Taiwan & -0.0029 & 0.0043 & 0.0076 & 0.0070 & 0.0054 & $0.0083^{* * *}$ & $0.0090^{* * *}$ \\
\hline Thailand & -0.0062 & -0.0014 & 0.0062 & 0.0087 & 0.0102 & $0.0163^{* * *}$ & $0.0120^{* * *}$ \\
\hline UK & 0.0001 & 0.0038 & 0.0035 & 0.0053 & 0.0053 & $0.0053^{* * *}$ & $0.0031^{* *}$ \\
\hline US & -0.0010 & 0.0034 & 0.0049 & 0.0067 & 0.006 & $0.0070^{* * *}$ & $0.0033^{*}$ \\
\hline
\end{tabular}


Table 6. Return Regressions: Factor-Based-Model Expected-Return Estimates

Table 6 reports the results of Fama-MacBeth regressions of future simple returns on different ERPs. Columns under FF Global and FF Regional report regression of realized simple returns on ERPs generated using firm-specific loadings on the Fama-French global four factors and the regional four factors, respectively. Expected factor returns are estimated based on trailing 40-month averages, and factor loadings are estimated based using data available in the 40 months prior to the forecast date. For comparison, we create proxies of expected simple returns computed as $\hat{\mathbb{E}}_{t}\left[R_{i, t+1}\right]=\exp \left(\hat{\mu}_{i, t}+0.5 \times \hat{\sigma}_{i, t+1}^{2}\right)$, where $\hat{\mu}_{i, t}$ is our expected $\log$ return estimate, and $\hat{\sigma}_{i, t+1}^{2}$ is an estimate of the expected volatility in $\log$ returns based on the average squared daily returns from the prior month scaled by 252/12. Regression-based tests using simple returns and these proxies are reported in columns under the heading CLW. The analyses are conducted on a common set of firm-year observations for which all ERPs are available. All ERPs are winsorized at the top and bottom one percent. Columns under the heading $\hat{\mathbb{E}}\left[r_{i, t+1}\right]$ reports the slope coefficient on the ERP, Cons reports the coefficient on the constant term, and $p$ reports $p$-values corresponding to the F-test of the null that the slope coefficient is equal to 1 . Levels of significance are indicated by *, **, and ***, representing 10 percent, 5 percent, and 1 percent, respectively.

\begin{tabular}{|c|c|c|c|c|c|c|c|c|c|c|}
\hline \multirow[b]{2}{*}{ Country } & \multicolumn{3}{|c|}{ CLW } & \multicolumn{3}{|c|}{ FF Global } & \multicolumn{3}{|c|}{ FF Regional } & \multirow[b]{2}{*}{$\mathrm{N}$} \\
\hline & $\hat{\mathbb{E}}\left[r_{i, t+1}\right]$ & Cons & $p$ & $\hat{\mathbb{E}}\left[r_{i, t+1}\right]$ & Cons & $p$ & $\hat{\mathbb{E}}\left[r_{i, t+1}\right]$ & Cons & $p$ & \\
\hline Australia & $0.5530 * *$ & $0.0082^{* *}$ & 0.047 & -0.0772 & 0.0026 & 0.000 & -0.0082 & $0.0118^{* * *}$ & 0.000 & 64,374 \\
\hline Belgium & $0.6807^{* *}$ & 0.0045 & 0.227 & -0.2375 & $-0.0185^{*}$ & 0.000 & 0.0284 & 0.0070 & 0.004 & 9,654 \\
\hline Canada & $0.4700^{* * *}$ & $0.0059^{* *}$ & 0.000 & 0.0019 & 0.0234 & 0.000 & $-0.2233^{* * *}$ & $0.0123^{* * *}$ & 0.000 & 43,212 \\
\hline China & $3.5899^{* * *}$ & -0.0073 & 0.000 & -0.0100 & $0.0271^{* *}$ & 0.000 & -0.1794 & $0.0222^{* *}$ & 0.000 & 172,531 \\
\hline Denmark & $1.0543^{* * *}$ & -0.0006 & 0.816 & $-0.3165^{* *}$ & $0.0370^{* * *}$ & 0.000 & -0.0174 & $0.0124^{* *}$ & 0.000 & 19,089 \\
\hline Finland & $0.4946^{* *}$ & 0.0028 & 0.039 & -0.1025 & 0.0167 & 0.000 & $-1.1804^{* *}$ & 0.0005 & 0.000 & 6,438 \\
\hline France & $1.0689^{* * *}$ & -0.0008 & 0.715 & 0.0194 & 0.0101 & 0.000 & -0.0187 & $0.0083^{* *}$ & 0.000 & 112,612 \\
\hline Germany & $0.7193^{* * *}$ & 0.0016 & 0.121 & -0.0255 & -0.0126 & 0.000 & -0.1012 & 0.0048 & 0.000 & 99,671 \\
\hline Greece & $1.0357^{* *}$ & -0.0059 & 0.933 & -0.0277 & -0.0120 & 0.000 & 0.7443 & 0.0021 & 0.638 & 9,058 \\
\hline HongKong & $2.2628^{* * *}$ & $0.0070^{*}$ & 0.000 & $-0.2135^{*}$ & -0.0029 & 0.000 & 0.1131 & $0.0140^{* * *}$ & 0.000 & 50,424 \\
\hline India & $3.7759^{* * *}$ & $-0.0331 * * *$ & 0.000 & -0.0797 & $0.0232 *$ & 0.000 & -0.0447 & $0.0222^{* * *}$ & 0.000 & 183,428 \\
\hline Indonesia & $2.1836^{* * *}$ & -0.0173 & 0.051 & $-0.2492 * *$ & $0.0365^{* * *}$ & 0.000 & -0.1593 & $0.0302^{* * *}$ & 0.000 & 30,706 \\
\hline Israel & $1.3927^{* * *}$ & 0.0145 & 0.372 & $-0.3088^{* *}$ & $0.0188^{* *}$ & 0.000 & -0.1569 & $0.0157^{*}$ & 0.000 & 7,801 \\
\hline Italy & $2.9696^{* * *}$ & 0.0033 & 0.000 & -0.1301 & 0.0091 & 0.000 & -0.2258 & 0.0052 & 0.000 & 28,681 \\
\hline Japan & $2.3393^{* * *}$ & $-0.0069^{* *}$ & 0.000 & -0.0058 & -0.0141 & 0.000 & 0.0278 & 0.0039 & 0.000 & 683,671 \\
\hline Malaysia & $1.7983^{* * *}$ & $-0.0100 *$ & 0.000 & -0.0444 & 0.0055 & 0.000 & 0.1053 & 0.0067 & 0.000 & 75,221 \\
\hline Netherlands & $0.7825^{* * *}$ & 0.0071 & 0.424 & -0.2979 & 0.0120 & 0.000 & 0.3090 & $0.0102 *$ & 0.001 & 16,211 \\
\hline Norway & $1.3719^{* * *}$ & -0.0065 & 0.109 & -0.1321 & 0.0016 & 0.000 & -0.2061 & 0.0079 & 0.000 & 12,457 \\
\hline Pakistan & $2.0903^{* * *}$ & $-0.0221 * * *$ & 0.005 & $0.2596^{*}$ & $0.0143^{*}$ & 0.000 & -0.0936 & $0.0163^{*}$ & 0.000 & 16,179 \\
\hline Philippines & $1.9876^{* * *}$ & $-0.0217^{* *}$ & 0.023 & -0.1057 & $0.0183^{* *}$ & 0.000 & 0.2794 & $0.0167^{*}$ & 0.027 & 5,813 \\
\hline S_Africa & $0.6764^{* * *}$ & 0.0103* & 0.019 & 0.0044 & $0.0403^{* * *}$ & 0.000 & 0.2063 & $0.0170^{* * *}$ & 0.000 & 30,745 \\
\hline Korea_S & $3.0504^{* * *}$ & 0.0011 & 0.000 & -0.0023 & 0.0278 & 0.000 & -0.0699 & $0.0160 *$ & 0.000 & 204,707 \\
\hline Spain & $1.9934 * * *$ & 0.0002 & 0.003 & -0.1359 & -0.0059 & 0.000 & 0.3016 & $0.0095 *$ & 0.007 & 15,847 \\
\hline Sweden & $1.2380^{* * *}$ & 0.0070 & 0.188 & 0.0204 & 0.0142 & 0.000 & -0.0884 & $0.0143^{* *}$ & 0.000 & 40,511 \\
\hline Switzerland & $1.0388^{* * *}$ & $0.0080^{* *}$ & 0.873 & -0.1153 & -0.0107 & 0.000 & -0.0330 & $0.0084^{* *}$ & 0.000 & 27,691 \\
\hline Taiwan & $3.5363^{* * *}$ & $0.0147^{* *}$ & 0.000 & -0.0783 & 0.0027 & 0.000 & 0.1934 & $0.0157^{* *}$ & 0.000 & 81,252 \\
\hline Thailand & $1.6473^{* * *}$ & 0.0096 & 0.000 & -0.0212 & -0.0196 & 0.000 & $-0.2078^{*}$ & $0.0172^{* *}$ & 0.000 & 65,056 \\
\hline UK & $1.0344^{* * *}$ & 0.0025 & 0.873 & -0.0126 & 0.0091 & 0.000 & -0.1291 & $0.0080^{* * *}$ & 0.000 & 161,469 \\
\hline USA & $0.7782^{* * *}$ & 0.0033* & 0.051 & -0.0924 & $0.0233^{*}$ & 0.000 & $-0.0660^{*}$ & $0.0132^{* * *}$ & 0.000 & $1,069,316$ \\
\hline 5-Factor & & & & & & & -0.0385 & $0.0127^{* * *}$ & 0.000 & $1,069,316$ \\
\hline 3-Factor & & & & & & & $-0.1031 *$ & $0.0134^{* * *}$ & 0.000 & $1,069,316$ \\
\hline
\end{tabular}


Table 7. Dividend Payout and Relations between Expected Returns and Accounting Fundamentals

Table 7 reports the country-level results on the estimation of (18). We run Fama-MacBeth regressions of future realized annual log stock returns, $r_{t+1}$, on firm characteristics, $b m_{t}, r_{0} e_{t+1}$, labeled as froe in the table, and payout $t_{t+1}$, a continuous variable computed as Dividends $s_{t+1} / B_{0 o k_{t+1}}$. The variables $b m \times$ payout and froe $\times$ payoutrepresent interactions of payout with $b m$ and froe, respectively. payout is winsorized at the 1-percent level. Standard errors are reported in brackets below the coefficient estimates. Levels of significance are indicated by ${ }^{*},{ }^{* *}$, and ${ }^{* * *}$, representing 10 percent, 5 percent, and 1 percent, respectively.

\begin{tabular}{|c|c|c|c|c|c|c|c|c|c|c|}
\hline & Australia & Belgium & Canada & China & Denmark & Finland & France & Germany & Greece & Hong Kong \\
\hline$b m$ & $\begin{array}{c}0.0424^{* *} \\
{[0.020]}\end{array}$ & $\begin{array}{l}0.0206 \\
{[0.042]}\end{array}$ & $\begin{array}{c}0.0602^{* *} \\
{[0.023]}\end{array}$ & $\begin{array}{c}0.0721^{* * *} \\
{[0.016]}\end{array}$ & $\begin{array}{l}0.0344 \\
{[0.033]}\end{array}$ & $\begin{array}{c}0.0947^{*} \\
{[0.030]}\end{array}$ & $\begin{array}{c}0.0554^{* * *} \\
{[0.014]}\end{array}$ & $\begin{array}{c}0.0581 * * * \\
{[0.021]}\end{array}$ & $\begin{array}{c}0.0761^{* *} \\
{[0.023]}\end{array}$ & $\begin{array}{c}0.0859^{* * *} \\
{[0.022]}\end{array}$ \\
\hline froe & $\begin{array}{c}0.1183^{* *} \\
{[0.056]}\end{array}$ & $\begin{array}{c}0.4580^{* * * *} \\
{[0.058]}\end{array}$ & $\begin{array}{c}0.3951^{* * * *} \\
{[0.101]}\end{array}$ & $\begin{array}{c}0.2718^{* * * *} \\
{[0.069]}\end{array}$ & $\begin{array}{c}0.4020^{* * * *} \\
{[0.091]}\end{array}$ & $\begin{array}{c}0.5090^{* * * *} \\
{[0.072]}\end{array}$ & $\begin{array}{c}0.4231^{* * *} \\
{[0.049]}\end{array}$ & $\begin{array}{c}0.2707 * * * \\
{[0.037]}\end{array}$ & $\begin{array}{c}0.4907 * * * \\
{[0.091]}\end{array}$ & $\begin{array}{c}0.4655^{* * * *} \\
{[0.156]}\end{array}$ \\
\hline payout & $\begin{array}{l}0.3582 \\
{[0.214]}\end{array}$ & $\begin{array}{c}2.1520^{* *} \\
{[0.442]}\end{array}$ & $\begin{array}{c}-0.1976 \\
{[0.395]}\end{array}$ & $\begin{array}{c}-0.6139 \\
{[1.162]}\end{array}$ & $\begin{array}{c}1.4684^{* *} \\
{[0.569]}\end{array}$ & $\begin{array}{c}1.2045^{*} \\
{[0.408]}\end{array}$ & $\begin{array}{l}0.5462 \\
{[0.320]}\end{array}$ & $\begin{array}{c}0.8191^{* * *} \\
{[0.209]}\end{array}$ & $\begin{array}{c}2.0232 * * * \\
{[0.499]}\end{array}$ & $\begin{array}{c}0.8740^{* *} \\
{[0.343]}\end{array}$ \\
\hline bm $\times$ payout & $\begin{array}{c}0.4629^{* * *} * \\
{[0.151]}\end{array}$ & $\begin{array}{c}1.4412^{*} \\
{[0.580]}\end{array}$ & $\begin{array}{l}0.2061 \\
{[0.343]}\end{array}$ & $\begin{array}{c}0.8498^{* *} \\
{[0.361]}\end{array}$ & $\begin{array}{c}1.2337^{* * *} \\
{[0.354]}\end{array}$ & $\begin{array}{c}0.6640^{* *} \\
{[0.168]}\end{array}$ & $\begin{array}{c}-0.0775 \\
{[0.291]}\end{array}$ & $\begin{array}{c}0.5326^{* *} \\
{[0.217]}\end{array}$ & $\begin{array}{c}1.3149 * * * \\
{[0.361]}\end{array}$ & $\begin{array}{c}0.4819^{* *} \\
{[0.214]}\end{array}$ \\
\hline froe $\times$ payout & $\begin{array}{c}1.8429^{* *} \\
{[0.747]}\end{array}$ & $\begin{array}{l}1.5300 \\
{[3.268]}\end{array}$ & $\begin{array}{l}2.0541 \\
{[1.547]}\end{array}$ & $\begin{array}{l}4.8886 \\
{[3.904]}\end{array}$ & $\begin{array}{l}3.5593^{*} \\
{[1.954]}\end{array}$ & $\begin{array}{l}1.5894 \\
{[1.816]}\end{array}$ & $\begin{array}{l}-0.9048 \\
{[1.294]}\end{array}$ & $\begin{array}{c}3.8656^{* *} \\
{[1.611]}\end{array}$ & $\begin{array}{l}1.9315 \\
{[1.241]}\end{array}$ & $\begin{array}{l}1.1293 \\
{[1.514]}\end{array}$ \\
\hline Cons & $\begin{array}{c}0.0927^{* * *} \\
{[0.031]}\end{array}$ & $\begin{array}{l}-0.1203 \\
{[0.122]}\end{array}$ & $\begin{array}{l}0.0312 \\
{[0.033]}\end{array}$ & $\begin{array}{l}0.0929 \\
{[0.091]}\end{array}$ & $\begin{array}{l}0.0010 \\
{[0.075]}\end{array}$ & $\begin{array}{l}-0.1041 \\
{[0.158]}\end{array}$ & $\begin{array}{l}0.0224 \\
{[0.043]}\end{array}$ & $\begin{array}{c}-0.0038 \\
{[0.042]}\end{array}$ & $\begin{array}{l}-0.0820 \\
{[0.108]}\end{array}$ & $\begin{array}{l}0.0395 \\
{[0.044]}\end{array}$ \\
\hline $\begin{array}{l}\mathrm{N} \\
\text { Adj } R^{2} \\
\end{array}$ & $\begin{array}{l}4,849 \\
0.086 \\
\end{array}$ & $\begin{array}{c}424 \\
0.175 \\
\end{array}$ & $\begin{array}{l}3,867 \\
0.121 \\
\end{array}$ & $\begin{array}{c}14,207 \\
0.091 \\
\end{array}$ & $\begin{array}{l}1,886 \\
0.185 \\
\end{array}$ & $\begin{array}{c}416 \\
0.145 \\
\end{array}$ & $\begin{array}{l}9,707 \\
0.128 \\
\end{array}$ & $\begin{array}{l}8,608 \\
0.143 \\
\end{array}$ & $\begin{array}{l}1,088 \\
0.135 \\
\end{array}$ & $\begin{array}{l}3,965 \\
0.130 \\
\end{array}$ \\
\hline & India & Indonesia & Israel & Italy & Japan & Malaysia & Netherlands & Norway & Pakistan & Philippines \\
\hline$b m$ & $\begin{array}{c}0.0437^{* *} \\
{[0.018]}\end{array}$ & $\begin{array}{c}0.1212^{* * *} \\
{[0.019]}\end{array}$ & $\begin{array}{l}0.0249 \\
{[0.026]}\end{array}$ & $\begin{array}{l}0.0309 \\
{[0.020]}\end{array}$ & $\begin{array}{c}0.0594^{* * *} \\
{[0.010]}\end{array}$ & $\begin{array}{c}0.0933^{* * *} \\
{[0.023]}\end{array}$ & $\begin{array}{c}0.0644^{*} \\
{[0.033]}\end{array}$ & $\begin{array}{l}0.0199 \\
{[0.021]}\end{array}$ & $\begin{array}{l}0.0352 \\
{[0.024]}\end{array}$ & $\begin{array}{l}0.0480 \\
{[0.032]}\end{array}$ \\
\hline froe & $\begin{array}{l}0.0428 \\
{[0.058]}\end{array}$ & $\begin{array}{c}0.4699^{* * *} * \\
{[0.099]}\end{array}$ & $\begin{array}{c}0.3244^{* * *} * \\
{[0.055]}\end{array}$ & $\begin{array}{c}0.3959^{* * *} * \\
{[0.064]}\end{array}$ & $\begin{array}{c}0.0677^{* * *} \\
{[0.023]}\end{array}$ & $\begin{array}{c}0.3676^{* * * *} \\
{[0.119]}\end{array}$ & $\begin{array}{c}0.4499^{* * *} \\
{[0.126]}\end{array}$ & $\begin{array}{c}0.2972^{* * *} \\
{[0.061]}\end{array}$ & $\begin{array}{c}0.2220^{* *} \\
{[0.075]}\end{array}$ & $\begin{array}{l}0.1309 \\
{[0.089]}\end{array}$ \\
\hline payout & $\begin{array}{c}2.5548^{* * * *} \\
{[0.708]}\end{array}$ & $\begin{array}{l}1.5426 \\
{[4.648]}\end{array}$ & $\begin{array}{c}0.8666^{* *} \\
{[0.222]}\end{array}$ & $\begin{array}{c}1.3632^{* * *} \\
{[0.437]}\end{array}$ & $\begin{array}{l}1.3688 \\
{[0.807]}\end{array}$ & $\begin{array}{c}1.7060^{* *} \\
{[0.624]}\end{array}$ & $\begin{array}{c}1.0725^{* * *} * \\
{[0.350]}\end{array}$ & $\begin{array}{c}1.3328^{* *} \\
{[0.509]}\end{array}$ & $\begin{array}{l}0.1186 \\
{[0.512]}\end{array}$ & $\begin{array}{c}-0.2669 \\
{[0.334]}\end{array}$ \\
\hline bm $\times$ payout & $\begin{array}{c}0.6496^{* *} \\
{[0.230]}\end{array}$ & $\begin{array}{c}7.3759 \\
{[11.419]}\end{array}$ & $\begin{array}{c}1.0607^{* *} \\
{[0.309]}\end{array}$ & $\begin{array}{c}1.3288^{* * *} \\
{[0.393]}\end{array}$ & $\begin{array}{c}0.9676^{* * * *} \\
{[0.338]}\end{array}$ & $\begin{array}{c}1.3732^{* * * *} \\
{[0.357]}\end{array}$ & $\begin{array}{c}0.8743^{* *} \\
{[0.301]}\end{array}$ & $\begin{array}{c}1.1769^{* *} \\
{[0.395]}\end{array}$ & $\begin{array}{c}0.7299 * * * \\
{[0.182]}\end{array}$ & $\begin{array}{c}1.3879^{* *} \\
{[0.378]}\end{array}$ \\
\hline froe $\times$ payout & $\begin{array}{c}-0.4167 \\
{[1.403]}\end{array}$ & $\begin{array}{l}11.6932 \\
{[17.377]}\end{array}$ & $\begin{array}{l}2.4046 \\
{[1.404]}\end{array}$ & $\begin{array}{l}3.2815 \\
{[2.970]}\end{array}$ & $\begin{array}{c}4.7387^{* *} \\
{[2.027]}\end{array}$ & $\begin{array}{c}4.5108^{* *} \\
{[1.732]}\end{array}$ & $\begin{array}{l}2.0722 \\
{[1.326]}\end{array}$ & $\begin{array}{c}2.0203^{*} \\
{[0.960]}\end{array}$ & $\begin{array}{c}4.3875^{* * * *} \\
{[1.169]}\end{array}$ & $\begin{array}{c}10.6006^{* * *} \\
{[1.063]}\end{array}$ \\
\hline Cons & $\begin{array}{l}0.0312 \\
{[0.085]}\end{array}$ & $\begin{array}{l}0.0988 \\
{[0.083]}\end{array}$ & $\begin{array}{l}0.0167 \\
{[0.076]}\end{array}$ & $\begin{array}{l}0.0116 \\
{[0.067]}\end{array}$ & $\begin{array}{c}-0.0175 \\
{[0.055]}\end{array}$ & $\begin{array}{l}0.0257 \\
{[0.070]}\end{array}$ & $\begin{array}{c}-0.0072 \\
{[0.062]}\end{array}$ & $\begin{array}{l}0.0122 \\
{[0.086]}\end{array}$ & $\begin{array}{l}0.0437 \\
{[0.121]}\end{array}$ & $\begin{array}{c}0.1713^{* *} \\
{[0.030]}\end{array}$ \\
\hline $\mathrm{N}$ & 13,663 & 2,973 & 1,060 & 2,786 & 60,045 & 5,917 & 1,878 & 1,193 & 1,658 & 570 \\
\hline $\operatorname{Adj} R^{2}$ & 0.079 & 0.146 & 0.137 & 0.164 & 0.058 & 0.122 & 0.178 & 0.131 & 0.123 & 0.093 \\
\hline
\end{tabular}




\section{Table 8. Earnings Quality and Importance of ROE}

Table 8 reports the results of OLS and instrumental-variables (IV) regressions of country-level median roe coefficients, from monthly regressions of Eq., (13), on measures of earnings quality. Our overall earnings quality measure follows Leuz et al. (2003): a simple average of a country's in-sample ranks on four dimensions of earnings quality: earnings smoothness, correlation of accruals and cash flows, accruals magnitude, and loss avoidance. These four variables are defined in Table 9. A higher score on each of these dimensions, and on the overall earnings-quality measure, implies lower or poorer earnings quality. The leftmost column reports the results of an OLS regression of the median roe coefficients on overall earnings quality. The second and third columns report the first and second stage results, respectively, of instrumental variables regressions where earnings quality is instrumented with a measure for a country's quality of governance institutions. This quality of governance measures combines information on a country's Rule of Law, Accountability, Political Stability, Government Effectiveness, and Control of Corruption, as reported by the World Bank's Worldwide Governance Indicators project. Rule of Law captures perceptions of the quality of contract enforcement, property rights, and the courts; Accountability captures perceptions of the extent to which citizens have the ability to exert their voices and influence to create accountability in society, including freedom to select their government and the presence of a free media; Political Stability measures perceptions of the likelihood of political instability; Government Effectiveness captures perceptions of the quality of public services and the robustness of the policy formulation process; and Control of Corruption captures perceptions of the extent to which public power is exercised for private benefits. We take the median value of each variable over the relevant time frame for each country and then standardize each measure using the cross-section of countries. Our final country-level measure is the simple average of these standardized measures. In the last column we report reduced-form versions of the IV estimation. The F-statistic on the instrument is reported in the last row. In each of these regressions we control for the log of a given country's median total market capitalization over the relevant time frame. Levels of significance are indicated by $*$, **, and ${ }^{* * *}$, representing 10 percent, 5 percent, and 1 percent, respectively.

\begin{tabular}{|c|c|c|c|c|}
\hline & OLS & $\begin{array}{c}\text { IV } \\
\text { First Stage }\end{array}$ & $\begin{array}{c}\text { IV } \\
\text { Second Stage }\end{array}$ & $\begin{array}{l}\text { Reduced } \\
\text { Form }\end{array}$ \\
\hline Poor Information Quality (Leuz et al., 2003) & $\begin{array}{c}-0.0001 \\
{[0.000]}\end{array}$ & & $\begin{array}{c}-0.0007^{* *} \\
{[0.000]}\end{array}$ & \\
\hline Quality of Governance Institutions & & $\begin{array}{c}-3.9260 * * * \\
{[1.264]}\end{array}$ & & $\begin{array}{c}0.0027^{*} \\
{[0.001]}\end{array}$ \\
\hline Log Market Size & $\begin{array}{c}-0.0023^{* * *} \\
{[0.001]}\end{array}$ & $\begin{array}{c}-0.1859 \\
{[0.883]}\end{array}$ & $\begin{array}{c}-0.0030 * * * \\
{[0.001]}\end{array}$ & $\begin{array}{c}-0.0029^{* * *} \\
{[0.001]}\end{array}$ \\
\hline Constant & $\begin{array}{c}0.0750 * * * \\
{[0.023]}\end{array}$ & $\begin{array}{l}20.6885 \\
{[23.082]}\end{array}$ & $\begin{array}{c}0.1041^{* * *} \\
{[0.025]}\end{array}$ & $\begin{array}{c}0.0898^{* * *} \\
{[0.018]}\end{array}$ \\
\hline $\begin{array}{l}\text { Observations } \\
\text { First Stage F }\end{array}$ & 25 & $\begin{array}{c}25 \\
9.65\end{array}$ & 25 & 25 \\
\hline
\end{tabular}




\section{Table 9. Earnings Quality and Importance of ROE: Alternative Measures}

Table 9 reports the same specifications reported in Table 8 but uses Leuz et al. (2003)'s four measures of poor Information quality. Variability measures the extent to which a country's firms engage in earnings smoothing. In descending order, we rank each country's median ratio of firm-level standard deviation of operating earnings to the firm-level standard deviation of cash-flow from operations. A lower ratio implies a greater degree of earnings smoothing and thus lower earnings quality, resulting in a higher rank in Poor Information Quality. Correlation also measures the extent of earnings smoothing in a country. Across countries, in ascending order, we rank the magnitude of the contemporaneous correlation between changes in accounting accruals and changes in operating cash flows. This correlation is estimated by pooling all firm-years within a country. A greater magnitude of correlation implies greater earnings smoothing and lower earnings quality, resulting in a higher rank on Poor Information Quality. Accruals Magnitude proxies for the extent of the use of accruals to manage earnings. We rank, in ascending order, the median of the absolute value of firm accruals scaled by the absolute value of firm cash-flow from operations. A higher median ratio implies a greater use of accruals in managing earnings and lower earnings quality, resulting in a higher rank on Poor Information Quality. Lastly the Small Loss Avoidance measure ranks across countries, in ascending order, the ratio of instances of small profits to instances of small losses: this ratio is calculated by pooling all firm-years within a country. Small profits and small losses are calculated using earnings scaled by total assets. Small losses are defined as in the range $[-0.01,0)$ and small profits are defined as in the range [0.00, 0.01]. A higher ratio implies greater use of managerial discretion in managing earnings and lower earnings quality, and results in a higher rank in Poor Information Quality. Our instruments and control variables remain the same as in Table 8 . Levels of significance are indicated by + , *, **, and ***, representing 15 percent, 10 percent, 5 percent, and 1 percent, respectively.

\begin{tabular}{|c|c|c|c|c|c|c|c|c|c|c|c|c|}
\hline & \multicolumn{3}{|c|}{ Variability } & \multicolumn{3}{|c|}{ Correlation } & \multicolumn{3}{|c|}{ Accruals Magnitude } & \multicolumn{3}{|c|}{ Small Loss Avoidance } \\
\hline & OLS & IV & IV & OLS & IV & IV & OLS & IV & IV & OLS & IV & IV \\
\hline & & First Stage & Second Stage & & First Stage & Second Stage & & First Stage & Second Stage & & First Stage & Second Stage \\
\hline Poor Information Quality & $\begin{array}{l}0.0001 \\
{[0.000]}\end{array}$ & & $\begin{array}{l}-0.0009 \\
{[0.001]}\end{array}$ & $\begin{array}{l}0.0000 \\
{[0.000]}\end{array}$ & & $\begin{array}{c}-0.0006^{*} \\
{[0.000]}\end{array}$ & $\begin{array}{l}-0.0002 \\
{[0.000]}\end{array}$ & & $\begin{array}{c}-0.0006^{* *} \\
{[0.000]}\end{array}$ & $\begin{array}{l}-0.0000 \\
{[0.000]}\end{array}$ & & $\begin{array}{c}-0.0008^{*} \\
{[0.000]}\end{array}$ \\
\hline Quality of Governance & & $\begin{array}{c}-2.9232 \\
{[2.059]}\end{array}$ & & & $\begin{array}{c}-4.5851^{* * *} \\
{[1.537]}\end{array}$ & & & $\begin{array}{c}-4.8061^{* * *} \\
{[1.474]}\end{array}$ & & & $\begin{array}{c}-3.3898+ \\
{[2.145]}\end{array}$ & \\
\hline Log Market Size & $\begin{array}{c}-0.0022^{* * *} \\
{[0.001]}\end{array}$ & $\begin{array}{l}-0.2771 \\
{[1.332]}\end{array}$ & $\begin{array}{c}-0.0032^{* *} \\
{[0.001]}\end{array}$ & $\begin{array}{c}-0.0022^{* * *} \\
{[0.001]}\end{array}$ & $\begin{array}{l}0.0738 \\
{[1.253]}\end{array}$ & $\begin{array}{c}-0.0029^{* * *} \\
{[0.001]}\end{array}$ & $\begin{array}{c}-0.0027^{* * *} \\
{[0.001]}\end{array}$ & $\begin{array}{c}-1.4518+ \\
{[0.919]}\end{array}$ & $\begin{array}{c}-0.0037^{* * *} \\
{[0.001]}\end{array}$ & $\begin{array}{c}-0.0022^{* * *} \\
{[0.001]}\end{array}$ & $\begin{array}{l}0.9117 \\
{[1.142]}\end{array}$ & $\begin{array}{c}-0.0022^{* *} \\
{[0.001]}\end{array}$ \\
\hline Constant & $\begin{array}{c}0.0701^{* * *} \\
{[0.021]}\end{array}$ & $\begin{array}{l}22.4796 \\
{[35.373]}\end{array}$ & $\begin{array}{c}0.1107^{* * *} \\
{[0.041]}\end{array}$ & $\begin{array}{c}0.0725^{* * *} \\
{[0.019]}\end{array}$ & $\begin{array}{l}14.2393 \\
{[33.039]}\end{array}$ & $\begin{array}{c}0.0982^{* * *} \\
{[0.030]}\end{array}$ & $\begin{array}{c}0.0860 * * * \\
{[0.027]}\end{array}$ & $\begin{array}{c}53.8144^{* *} \\
{[24.410]}\end{array}$ & $\begin{array}{c}0.1203^{* * *} \\
{[0.025]}\end{array}$ & $\begin{array}{c}0.0731^{* * *} \\
{[0.018]}\end{array}$ & $\begin{array}{l}-7.7792 \\
{[30.393]}\end{array}$ & $\begin{array}{c}0.0835 * * * \\
{[0.023]}\end{array}$ \\
\hline $\begin{array}{l}\text { Observations } \\
\text { First Stage F }\end{array}$ & 25 & $\begin{array}{c}25 \\
2.02\end{array}$ & 25 & 25 & $\begin{array}{c}25 \\
8.90\end{array}$ & 25 & 25 & $\begin{array}{c}25 \\
10.63\end{array}$ & 25 & 25 & $\begin{array}{c}25 \\
2.50\end{array}$ & 25 \\
\hline
\end{tabular}

